\title{
ARTICLE
}

\section{Elimination of $\mathrm{CD} 4{ }^{\mathrm{low}} \mathrm{HLA}-\mathrm{G}^{+} \mathrm{T}$ cells overcomes castration- resistance in prostate cancer therapy}

\author{
Chao Wang ${ }^{1,2}$, Jiahuan Chen ${ }^{3}$, Qianfei Zhang ${ }^{1,2}$, Wang $\mathrm{Li}^{1}$, Shengbo Zhang ${ }^{1,2}$, Yanjie Xu ${ }^{1,2}$, Fang Wang ${ }^{1}$, Bing Zhang $^{3}$, Yan Zhang $^{1,2}$ and $^{1}$ \\ Wei-Qiang Gao ${ }^{1,2}$
}

\begin{abstract}
Androgen deprivation therapy (ADT) is a main treatment for prostate cancer (PCa) but the disease often recurs and becomes castration-resistant in nearly all patients. Recent data implicate the involvement of immune cells in the development of this castration-resistant prostate cancer (CRPC). In particular, T cells have been found to be expanded in both PCa patients and mouse models shortly after androgen deprivation. However, whether or which of the T cell subtypes play an important role during the development of CRPC is unknown. Here we identified a novel population of CD4 ${ }^{\text {low }} \mathrm{HLA}-\mathrm{G}^{+} \mathrm{T}$ cells that undergo significant expansion in PCa patients after ADT. In mouse PCa models, a similar CD4 ${ }^{\text {low }}$ T cell population expands during the early stages of CRPC onset. These cells are identified as IL-4-expressing $T_{H} 17$ cells, and are shown to be associated with CRPC onset in patients and essential for the development of CRPC in mouse models. Mechanistically, CD4 ${ }^{\text {low }} \mathrm{HLA}-\mathrm{G}^{+} \mathrm{T}$ cells drive androgen-independent growth of prostate cancer cells by modulating the activity and migration of $C D 11 b^{\text {low }} F 4 / 80^{\text {hi }}$ macrophages. Furthermore, following androgen deprivation, elevated $\mathrm{PGE}_{2}-\mathrm{EP} 2$ signaling inhibited the expression of CD4 in thymocytes, and subsequently induced the polarization of $C D 4{ }^{\text {low }}$ naïve $T$ cells towards the IL-4-expressing $T_{H} 17$ phenotype via up-regulation of IL23R. Therapeutically, inactivating $\mathrm{PGE}_{2}$ signaling with celecoxib at a time when $\mathrm{CD} 4{ }^{\mathrm{low}} \mathrm{HLA}-\mathrm{G}^{+} \mathrm{T}$ cells appeared, but not immediately following androgen deprivation, dramatically suppressed the onset of CRPC. Collectively, our results indicate that an unusual population of CD4 ${ }^{\text {low }} \mathrm{HLA}-$ $\mathrm{G}^{+} \mathrm{T}$ cells is essential for the development of CRPC and point to a new therapeutic avenue of combining ADT with PGE 2 inhibition for the treatment of prostate cancer.
\end{abstract}

Cell Research (2018) 28:1103-1117; https://doi.org/10.1038/s41422-018-0089-4

\section{INTRODUCTION}

Prostate cancer is the most commonly diagnosed cancer and the third leading cause of cancer-related deaths among men in western countries. ${ }^{1}$ Although androgen deprivation therapy (ADT), the main treatment for prostate cancer, is initially effective for most patients, the disease often recurs and becomes castrationresistant within 18 to 24 months. ${ }^{2,3}$ The mechanism underlying this castration-resistance remains poorly understood. ${ }^{4}$

Previous studies in mice and humans have reported that androgen ablation may activate thymic regeneration, elevate the absolute numbers of peripheral T cells, particularly $\mathrm{CD}^{+}{ }^{+} \mathrm{T}$ cells, and enhance the responsiveness of cytotoxic T lymphocytes (CTLs) to specific-antigen stimulation. ${ }^{5-7}$ Consistently, androgen ablation was found to remove the CD4 T cell tolerance to prostate tumorrestricted antigen, which allows these cells to expand and produce effector cytokines after vaccination with prostate-specific antigen. ${ }^{8}$ However, whether androgen ablation can trigger anti-tumor immunity still remains controversial. For example, recent studies have revealed that several types of immune cells, including $T, B$, $\mathrm{NK}$, and myeloid cells, infiltrate into the prostate tumor microenvironment after androgen ablation, which promotes castrationresistance of prostate cancer by activating IKK- $a$ and STAT3 in the tumor cells. ${ }^{9,10}$ The dual roles of immune cells in the progression of prostate cancer after ADT indicate that there might be a conversion from an anti-tumor to a pro-tumor immune response during the occurrence of CRPC. However, what drives this transition is still unknown.

Phenotypic and functional plasticity is a hallmark of several types of immune cells in the tumor microenvironment, especially CD4 $T$ helper $\left(T_{H}\right)$ cells, mediated by reciprocal interactions with tumor cells. ${ }^{11-13} \mathrm{CD}^{+} \mathrm{T}$ cells have been traditionally classified as $T_{H} 1, T_{H} 2, T_{H} 17$ cells, regulatory $T\left(T_{\text {reg }}\right)$ cells and $T$ follicular helper $\left(T_{F H}\right)$ cells, which are differentiated by their ability to express distinct transcriptional factors that result in the production of select cytokines and chemokine receptors. ${ }^{14}$ In particular, it has been demonstrated that $\mathrm{CD}^{+} \mathrm{T}$ cells can acquire characteristics of multiple $\mathrm{CD}^{+}{ }^{+} \mathrm{T}$ cell subsets simultaneously or at different times and to inter-convert between distinct $\mathrm{CD}^{+} \mathrm{T}$ cell subsets in response to changing circumstances. ${ }^{14-19}$ Therefore, we hypothesized that a specific subset of $\mathrm{CD} 4^{+} \mathrm{T}$ cells might play a vital role in the transition of the immune response to tumors after castration, which induces the onset of CRPC. In this study, we performed flow cytometric analysis of blood and tumor samples in both PCa patients and mouse models after ADT and discovered the expansion of a novel population of $\mathrm{CD}^{+} \mathrm{T}$ cells, CD4 ${ }^{\text {low }} \mathrm{HLA}-\mathrm{G}^{+}$ $\mathrm{T}$ cells, during the development of CRPC. More importantly, we

\footnotetext{
${ }^{1}$ State Key Laboratory of Oncogenes and Related Genes, Renji-MedX stem Cell Research Center, Ren Ji Hospital, School of Biomedical Engineering, Shanghai Jiao Tong University, Shanghai 200030, China; ${ }^{2}$ Med-X Research Institute \& School of Biomedical Engineering, Shanghai Jiao Tong University, Shanghai 200030 , China and ${ }^{3}$ Key Laboratory of Systems Biomedicine, Shanghai Center for Systems Biomedicine, Shanghai Jiao Tong University, Shanghai 200240, China

Correspondence: Yan Zhang (yanzh@sjtu.edu.cn) or Wei-Qiang Gao (gao.weiqiang@sjtu.edu.cn)
}

Received: 4 April 2018 Revised: 12 July 2018 Accepted: 26 August 2018

Published online: 8 October 2018 
1104

demonstrated that elimination of these specific cells dramatically inhibited the occurrence of CRPC. Thus, this study provides insight into the rational design of combination therapies involving the depletion of $\mathrm{CD} 4{ }^{\text {low }} \mathrm{HLA}-\mathrm{G}^{+}$T cells together with ADT for effective treatment of castration-resistant prostate cancer.

\section{RESULTS}

CD4 ${ }^{\text {low }} \mathrm{HLA}-\mathrm{G}^{+}$T cells are expanded in PCa patients with ADT To investigate whether and which of the $T$ cell subtypes play a crucial role during the development of CRPC, we collected blood samples from PCa patients and measured the proportions of different $T$ cells. Flow cytometric results revealed that the percentage of $\mathrm{CD}^{+} \mathrm{T}$ cells but not $\mathrm{CD}^{+} \mathrm{T}$ cells became significantly elevated in the peripheral blood of $\mathrm{PCa}$ patients with ADT (PCa/ADT), compared to those without ADT (PCa) (Fig. 1a, b; Supplementary information, Figs. S1a and S5a). Notably, a large population of $\mathrm{CD}^{\text {low }} \mathrm{T}$ cells appeared in the PCa/ADT patients (Fig. 1a, c; Supplementary information, Fig. S1b and c) and Wright staining showed that these cells displayed a spherical, rather than elongated or flattened morphology, which was a typical characteristic of $\mathrm{CD}^{+}{ }^{+} \mathrm{T}$ cells from healthy donors (HD) or $\mathrm{PCa}$ patients (Fig. 1C). Considering that previous studies showed that an immune-suppressive population of $\mathrm{CD} 4^{\text {low }} \mathrm{T}$ cells arises in allotransplantation, ${ }^{20}$ B-cell chronic lymphocytic leukemia ${ }^{21}$ and $\mathrm{HIV}^{22}$ we wondered whether these CD4 ${ }^{\text {low }} \mathrm{T}$ cells represent those immune-suppressive populations and examined the expression of several immunosuppression-related cell markers, such as FOXP3, CD25, HLA-G, TCRa $\beta$ and CD5 in these cells. Surprisingly, the $C D 4^{\text {low }} T$ cells neither expressed CD25 or FOXP3 nor up-regulated TCRaß or CD5 (Fig. 1d-f; Supplementary information, Fig. S2 a-c). Instead, the majority of these cells displayed high HLA-G expression (Fig. 1g), suggesting that $\mathrm{CD} 4{ }^{\text {low }} \mathrm{HLA}-\mathrm{G}^{+} \mathrm{T}$ cells might be a new subset of $C D 4^{+}$T cells distinct from $T_{\text {reg }}$ cells. In addition, flow cytometry and immunofluorescence staining revealed that CD4 ${ }^{\text {low }} \mathrm{HLA}^{+} \mathrm{G}^{+} \mathrm{T}$ cells also appeared in the tumors of PCa/ADT patients (Fig. 1h, i; Supplementary information, Fig. S3 a-c), mirroring results obtained from the peripheral blood.

$\mathrm{CD} 4{ }^{\text {low }} \mathrm{HLA}-\mathrm{G}^{+}$T cells are associated with CRPC occurrence in PCa patients

The relative proportion of $\mathrm{CD} 4^{\text {low }} \mathrm{HLA}_{-} \mathrm{G}^{+} \mathrm{T}$ cells was measured in the peripheral blood of age- and gender-matched HD $(n=10)$, PCa $(n=41)$ and PCa/ADT $(n=33)$ patients by flow cytometry (Supplementary information, Table S1). The percentage of $\mathrm{CD} 4{ }^{\text {low }} \mathrm{HLA}^{-\mathrm{G}^{+}} \mathrm{T}$ cells was robustly higher in the PCa/ADT group (Fig. 1j), independent of age, TNM stage and serum PSA level, as determined by univariate analyses (Supplementary information, Table S2). In addition, a case-control study of the same patient (Patient 18 in Supplementary information, Table S3) before and after ADT also showed that the frequencies of $\mathrm{CD} 4^{\text {low }} \mathrm{HLA}-\mathrm{G}^{+}$ $T$ cells were significantly increased in peripheral blood after ADT, compared to those measured before ADT (Supplementary information, Fig. S5a), echoing the results obtained from above population-based study. To explore the effect of CD4 ${ }^{\text {low }} \mathrm{HLA}_{-\mathrm{G}}{ }^{+}$ T cells on the onset of CRPC, the PCa/ADT group was first divided into two subgroups, CD4 ${ }^{\text {low }} \mathrm{HLA}-\mathrm{G}^{+}$-high and $\mathrm{CD} 4^{\text {low }} \mathrm{HLA}-\mathrm{G}^{+}$-low, based on the percentages of $\mathrm{CD} 4{ }^{\text {low }} \mathrm{HLA}-\mathrm{G}^{+} \mathrm{T}$ cells in peripheral blood. The cut-off value was determined by K-means clustering algorithm using SPSS19.0 (Supplementary information, Fig. S4 and Table S3). We then examined the correlation between disease (CRPC)-free survival (DFS) and the percentages of CD4 ${ }^{\text {low }} \mathrm{HLA}_{-} \mathrm{G}^{+}$ $T$ cells in these patients. Kaplan-Meier survival analyses showed that the patients in the CD4 ${ }^{\text {low }} \mathrm{HLA}-\mathrm{G}^{+}$-high group had significantly lower DFS times than those in the CD4 ${ }^{\text {low }} \mathrm{HLA}^{-\mathrm{G}^{+}}$-low group $(P=0.0058$, Fig. $1 \mathrm{k})$, indicating that patients in the CD4 ${ }^{\text {low }} \mathrm{HLA}-\mathrm{G}^{+}$high group more easily develop CRPC. Furthermore, patients in the $\mathrm{CD} 4{ }^{\text {low }} \mathrm{HLA}-\mathrm{G}^{+}$-high group had a more advanced disease, compared to those in $\mathrm{CD} 4{ }^{\text {low }} \mathrm{HLA}-\mathrm{G}^{+}$-low group, as judged by the decrease in overall survival (OS) times $(P=0.0073$, Fig. 1l). Notably though, flow cytometric data revealed that the CD4 ${ }^{\text {low }} \mathrm{HLA}-\mathrm{G}^{+}$ $T$ cells appeared at 2 months and disappeared at 36 months after ADT in PCa patients (Fig. $1 \mathrm{~m}$ ). A case-controlled study in same patients also showed that for patients in the $\mathrm{CD} 4^{\text {low }} \mathrm{HLA}-\mathrm{G}^{+}$-high group (Patient 12 and 25 in Supplementary information, Table S3), the levels of $\mathrm{CD} 4{ }^{\text {low }} \mathrm{HLA}-\mathrm{G}^{+} \mathrm{T}$ cells before the diagnosis of CRPC were significantly higher than those after the diagnosis of CRPC (Supplementary information, Fig. S5b and c). In contrast, for patients in the $\mathrm{CD} 4^{\text {low }} \mathrm{HLA}-\mathrm{G}^{+}$-low group who had not yet been diagnosed as CRPC (Patient 20 in Supplementary information, Table S3), the percentage of these cells remained at low level (Supplementary information, Fig. S5d). These results suggested that $\mathrm{CD}^{\text {low }}{ }^{\mathrm{HLA}-\mathrm{G}^{+}} \mathrm{T}$ cells were only expanded during the conversion from PCa to CRPC. Collectively, therefore, these results suggest that $\mathrm{CD} 4{ }^{\text {low }} \mathrm{HLA}-\mathrm{G}^{+}$T cells in the peripheral blood can be potentially used as an indicator for the initiation of CRPC formation, but only within three years after ADT.

\section{$\mathrm{CD} 4^{\text {low }} \mathrm{T}$ cells are detected in CRPC mouse models}

To further assess the critical role of $\mathrm{CD} 4{ }^{\text {low }} \mathrm{HLA}-\mathrm{G}^{+} \mathrm{T}$ cells on the occurrence of CRPC, we used the transgenic adenocarcinoma of mouse prostate (TRAMP) mouse model, in which the oncogene SV40 Tag is expressed under the control of the probasin promoter. ${ }^{23}$ As previously reported, ${ }^{24}$ TRAMP mice were castrated when they were 12-week-old (Fig. 2a) and by the age of about 24 weeks they gradually developed CRPC. This was confirmed by histopathologic analysis of the prostate, which revealed broken layers of a-SMA-positive smooth muscle cells, a significantly higher number of proliferating cells (Supplementary information, Fig. S6b and c), and a greater incidence of tumor-draining lymph nodes (TdLNs) and distant metastasis (Supplementary information, Fig. S6d and e), although the ratio of genitourinary (GU) tract weight to body weight (BW) showed no significant difference between castrated mice and sham-operation controls (Supplementary information, Fig. S6a). As expected, a considerable number of $\mathrm{CD}^{\text {low }} \mathrm{T}$ cells were also detected in the peripheral blood and primary tumor of CRPC mice but not in those of shamoperation controls (Fig. 2b, c, f, g). We then examined the expression of Qa2, a murine homolog of $\mathrm{HLA}_{-\mathrm{G}}{ }^{25}$ as a potential marker for the CD4 ${ }^{\text {low }} \mathrm{T}$ cells in the peripheral blood. We found, however, that Qa2 was not only expressed by $\mathrm{CD} 4{ }^{\text {low }} \mathrm{T}$ cells but also by $\mathrm{CD}^{+}{ }^{+} \mathrm{T}$ cells isolated from control groups and $\mathrm{CD}^{-}$cells (Supplementary information, Fig. S8), suggesting that Qa2 is not a useful marker for murine CD4 ${ }^{\text {low }} \mathrm{T}$ cells. These phenomena were also verified in the ProbCre/Pten ${ }^{f / / f l}$ prostate cancer model (Fig. $2 \mathrm{~d}$, e, h, i; Supplementary information, Fig. S7 a-d).

CD4 ${ }^{\text {low }}{\mathrm{HLA}-\mathrm{G}^{+}}^{\mathrm{T}}$ cells are IL-4-expressing $\mathrm{T}_{\mathrm{H}} 17$ cells

To determine whether the CD4 ${ }^{\text {low }} \mathrm{T}$ cells in the CRPC mouse models are murine homologs of the CD4 ${ }^{\text {low }} \mathrm{HLA}-\mathrm{G}^{+} \mathrm{T}$ cells in PCa/ ADT patients, the expression level of effector cytokines and key transcriptional factors, indicative of $T_{H} 1, T_{H} 2, T_{H} 17$ and $T_{\text {reg }}$ cells, were first examined in the CD4 ${ }^{\text {low }} \mathrm{HLA}_{-} \mathrm{G}^{+} \mathrm{T}$ cells isolated from the peripheral blood of PCa/ADT patients. RT-PCR and intracellular flow cytometry analyses revealed that IL-17A ( $\left.T_{H} 17\right)$, ROR-yt ( $\left.T_{H} 17\right)$ and IL-4 $\left(T_{H} 2\right)$ expression was dramatically increased in the

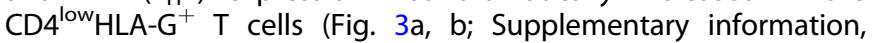
Fig. S9 $\mathrm{c}$ and e), whereas the expression of other cytokines and transcriptional factors, including GATA3 $\left(T_{H} 2\right)$, was low (Fig. 3a, b; Supplementary information, Fig. S9 $a-d)$, Thus, these results indicate that $\mathrm{CD} 4{ }^{\text {low }} \mathrm{HLA}-\mathrm{G}^{+} \mathrm{T}$ cells were IL-4-expressing $\mathrm{T}_{\mathrm{H}} 17$ cells but not $\mathrm{T}_{\mathrm{H}} 2$ cells. These observations were echoed by RNA-seq, which revealed that $C D 4{ }^{\text {low }}{ }^{H L A-G}{ }^{+}$T cells highly expressed $T_{H} 17-$ relevant genes but not typical $\mathrm{T}_{\mathrm{H}} 2$ - (such as GATA3, IL-5 and IL-13),

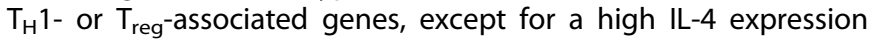
(Fig. 3c, left; Supplementary information, Fig. S10). 

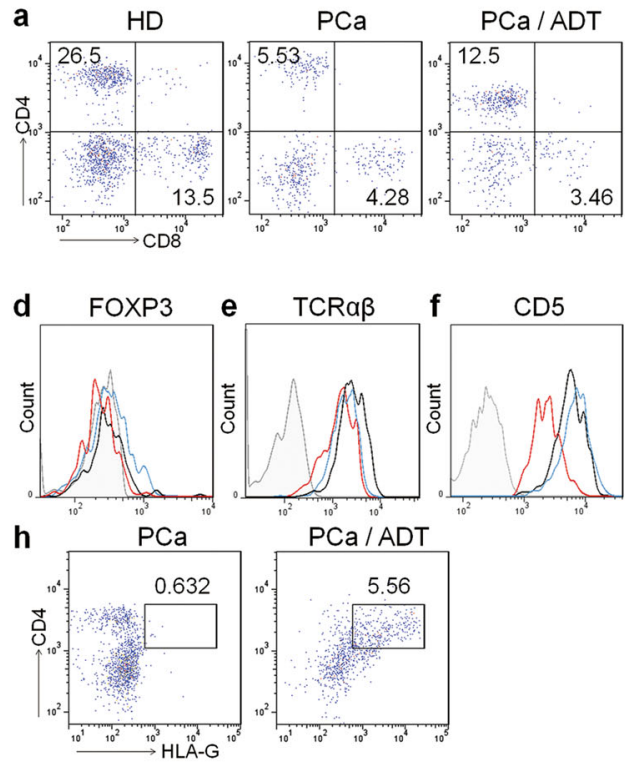

b
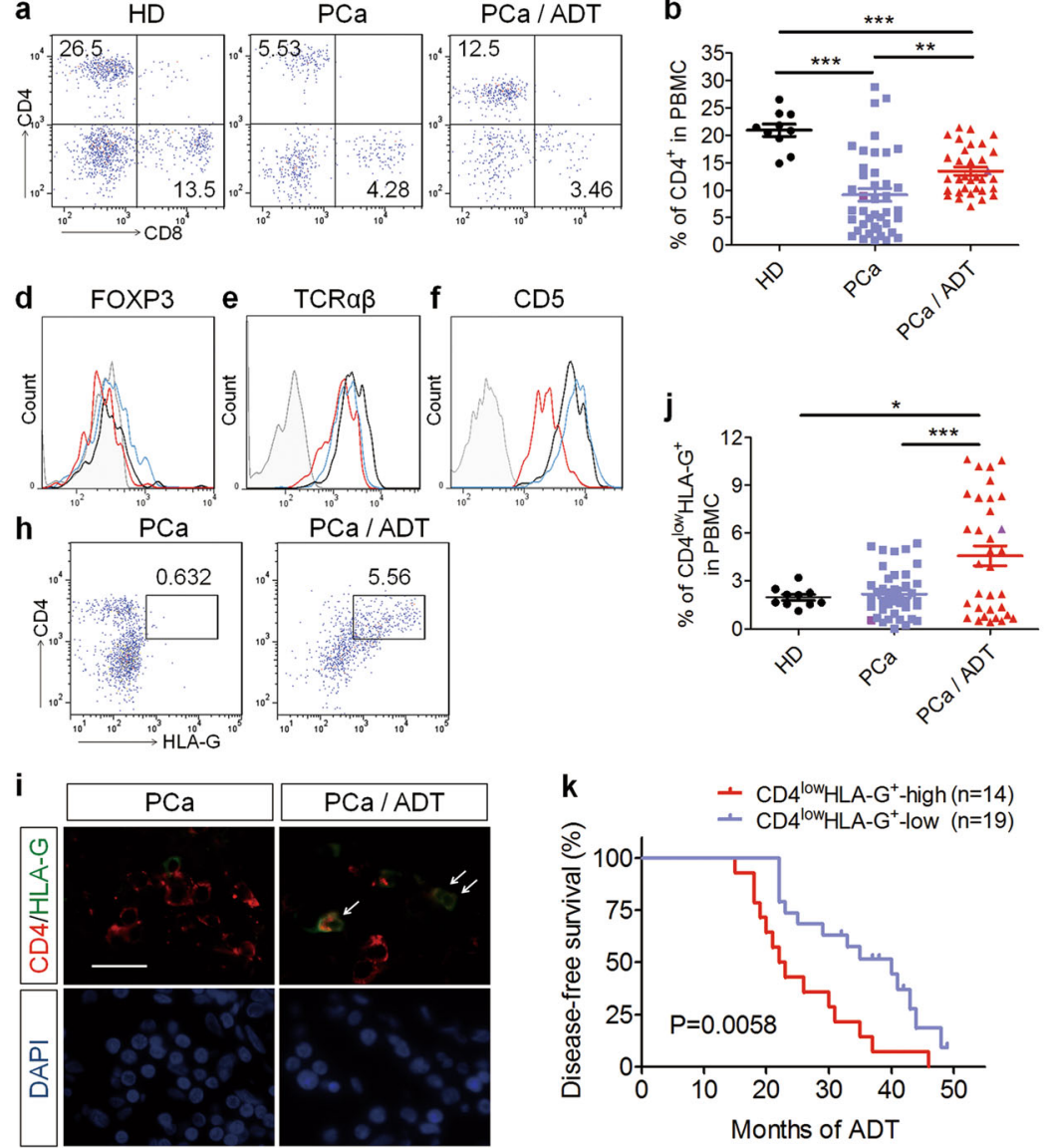
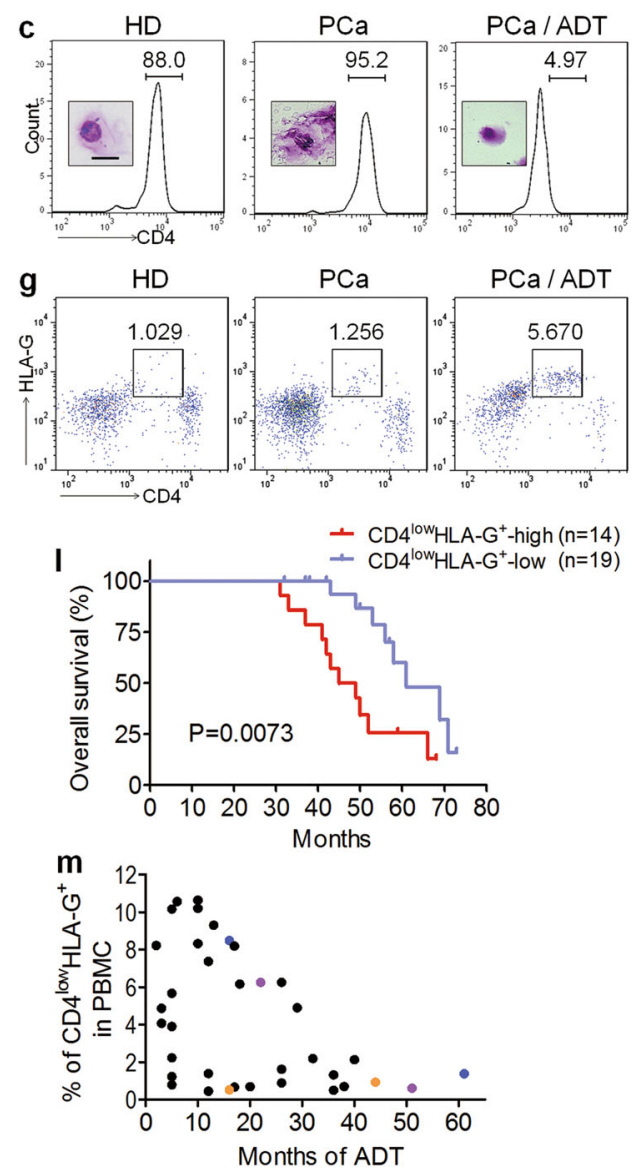

Fig. $1 \mathrm{CD} 4^{\text {low }} \mathrm{HLA}-\mathrm{G}^{+}$T cells are expanded in prostate cancer patients with ADT and associated with CRPC occurrence. a The representative images of $\mathrm{CD}^{+}$and $\mathrm{CD}^{+}$T-cell frequencies in peripheral blood of healthy donors $(n=10)$, PCa patients $(n=41)$ and PCa/ADT patients $(n=$ 33). b Quantification of (a). Flow cytometric data of Patient 18 in Supplementary information, Table S3 before and after ADT were incorporated into PCa and PCa/ADT groups, respectively (purple points). The flow cytometric images are presented in Supplementary information, Fig. S5a. c CD4 ${ }^{\text {hi }}$ T-cell frequencies in CD4 ${ }^{+}$T cells. Morphology of CD4 ${ }^{+}$T cells by Wright stain (insets). Scale bar, $10 \mu \mathrm{m}$. d-f FOXP3 (d), TCR $\alpha \beta$ (e) and CD5 (f) expression in peripheral blood CD4 ${ }^{+}$T cells from healthy donors (black line), PCa patients (blue line) and PCa/ADT patients (red line) by flow cytometry. g CD4 ${ }^{\text {low }} \mathrm{HLA}-\mathrm{G}^{+}$T-cell frequencies in peripheral blood. $\mathbf{h} \mathrm{CD}^{\mathrm{low}} \mathrm{HLA}^{-\mathrm{G}^{+}} \mathrm{T}$-cell frequencies in primary tumor. $\mathbf{i}$ Immunofluorescence microscopy of tumor in PCa and PCa/ADT patients showing CD4 ${ }^{\text {low }} \mathrm{HLA}_{-\mathrm{G}^{+}} \mathrm{T}$ cells (white arrow). Scale bar, $20 \mu \mathrm{m}$. $\mathbf{j}$ Percentage of CD4 ${ }^{\text {low }} \mathrm{HLA}-\mathrm{G}^{+}$T cells in peripheral blood of healthy donors $(n=10)$, PCa patients $(n=41)$ and PCa/ADT patients $(n=33)$. Flow cytometric data of Patient 18 is in Supplementary information, Table S3 before and after ADT were incorporated into PCa and PCa/ADT groups, respectively (purple points). The flow cytometric images are presented in Supplementary information, Fig. S5a. k and I Analyses following K-means unsupervised clustering of PCa/ADT patients shown in Supplementary information, Fig. S4. Disease-free survival of $\mathrm{CD} 4{ }^{\text {low }} \mathrm{HLA}-\mathrm{G}^{+}$-high patient subgroup $(n=14)$ compared to that of $\mathrm{CD} 4^{\text {low }} \mathrm{HLA}-\mathrm{G}^{+}$-low patient subgroup $(n=19)$ (median survival 22.5 vs. 40 months; $P=0.0058$, Hazard ratio (HR) $3.377,95 \% \mathrm{Cl} 1.424$ to 8.011$)$ (k). Overall survival of CD4 ${ }^{\text {low }} \mathrm{HLA}^{-\mathrm{G}^{+}}-\mathrm{high}_{\mathrm{g}}$ patient subgroup $(n=14)$ compared to that of $\mathrm{CD} 4{ }^{\text {low }} \mathrm{HLA}-\mathrm{G}^{+}$-low patient subgroup $(n=19)$ (median survival $47 \mathrm{vs.} 61$ months; $P=0.0073, \mathrm{HR} 4.016,95 \% \mathrm{Cl} 1.454$ to 11.09) (I). Disease-free, tumor remains but does not develop into CRPC after ADT. The formation of CRPC is diagnosed according to the PCa guidelines of European Association of Urology (EAU) (testosterone $<50 \mathrm{ng} / \mathrm{mL}$ and PSA $>2 \mathrm{ng} / \mathrm{mL}$ in serum for more than three months). $\mathbf{m}$ Frequencies of $C D 4^{\text {low }}{ }^{2}$ LA-G ${ }^{+}$T cells in peripheral blood of PCa patients following ADT treatment. The frequencies of CD4 ${ }^{\text {low }} \mathrm{HLA}^{-\mathrm{G}^{+}} \mathrm{T}_{\text {cells in }}$ peripheral blood of three representative patients in the two subgroups, respectively, before or after the diagnosis of CRPC are presented (Patients 12 and 25 in CD4 ${ }^{\text {low } H L A-G^{+}}$-high subgroup, blue and purple points, respectively; Patient 20 in CD4 ${ }^{\text {low }}{ }^{-}$LA-G ${ }^{+}$-low subgroup, yellow points). The flow cytometric images are shown in Supplementary information, Fig. S5. b-d Mean $\pm \mathrm{SEM},{ }^{*} P<0.05,{ }^{* *} P<0.01,{ }^{* * *} P<0.001$ by $t$ tests $(\mathbf{b}, \mathbf{j})$, log-rank analysis $(\mathbf{k}, \mathbf{l})$

We then compared the murine $\mathrm{CD} 4^{\text {low }} \mathrm{T}$ cells isolated from the peripheral blood of CRPC TRAMP mice with human CD4 ${ }^{\text {low }} \mathrm{HLA}_{-\mathrm{G}}^{+}$ T cells by RNA-seq. The results showed that the expression profile of the $\mathrm{CD} 4^{\text {low }} \mathrm{T}$ cells resembled that of the $\mathrm{CD} 4^{\text {low }} \mathrm{HLA}-\mathrm{G}^{+} \mathrm{T}$ cells, with a high expression of $\mathrm{T}_{\mathrm{H}}$ 17-relevant genes and IL-4 and not of typical genes of other CD4 T-cell subsets (Fig. 3c, right; Supplementary information, Fig. S11). The expression levels of typical $\mathrm{T}_{\mathrm{H}} 2$ - and $\mathrm{T}_{\mathrm{H}} 17$-associated effector cytokines and transcriptional factors in the peripheral blood $C D 4^{\text {low }} \mathrm{T}$ cells from CRPC TRAMP mice were also analyzed by RT-PCR and intracellular flow cytometry. We found that the expression level of IL-17A, ROR- $y t$ and IL-4 but not GATA3 was dramatically higher in CD4 $4^{\text {low }} \mathrm{T}$ cells than in $\mathrm{CD}^{+}{ }^{+}$cells from the wild-type and PCa groups (Fig. 3d, e; Supplementary information, Fig. S12a, c). These results were also verified in the ProbCre/Pten ${ }^{f / f}$ prostate cancer mouse model (Fig. 3f, g; Supplementary information, Fig. S12b).

To further confirm the characterization of intratumoral $\mathrm{CD} 4{ }^{\text {low }} \mathrm{HLA}-\mathrm{G}^{+} \mathrm{T}$ cells in PCa/ADT patients, the expression levels of $T_{H} 2$ - and $T_{H}$ 17-relevant effector cytokines and key transcriptional factors in $\mathrm{CD} 4{ }^{\text {low }} \mathrm{HLA}_{-\mathrm{G}^{+}} \mathrm{T}$ cells isolated from primary tumors of PCa/ADT patients were measured by RT-PCR. As shown in the,Supplementary information Fig. S13a the expression levels of IL-4, IL17A and RORyt but not GATA3 were significantly increased in these cells compared to those in $\mathrm{CD}^{+} \mathrm{T}$ cells from 
a

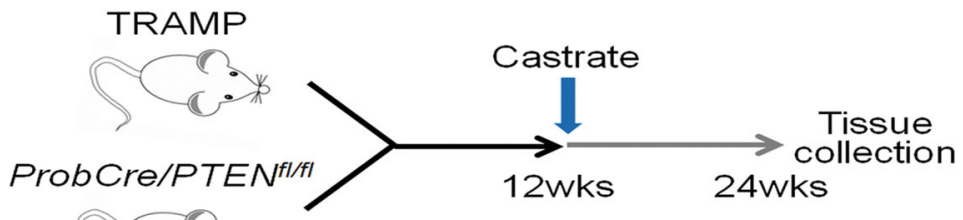

b

PBMC (TRAMP mice)
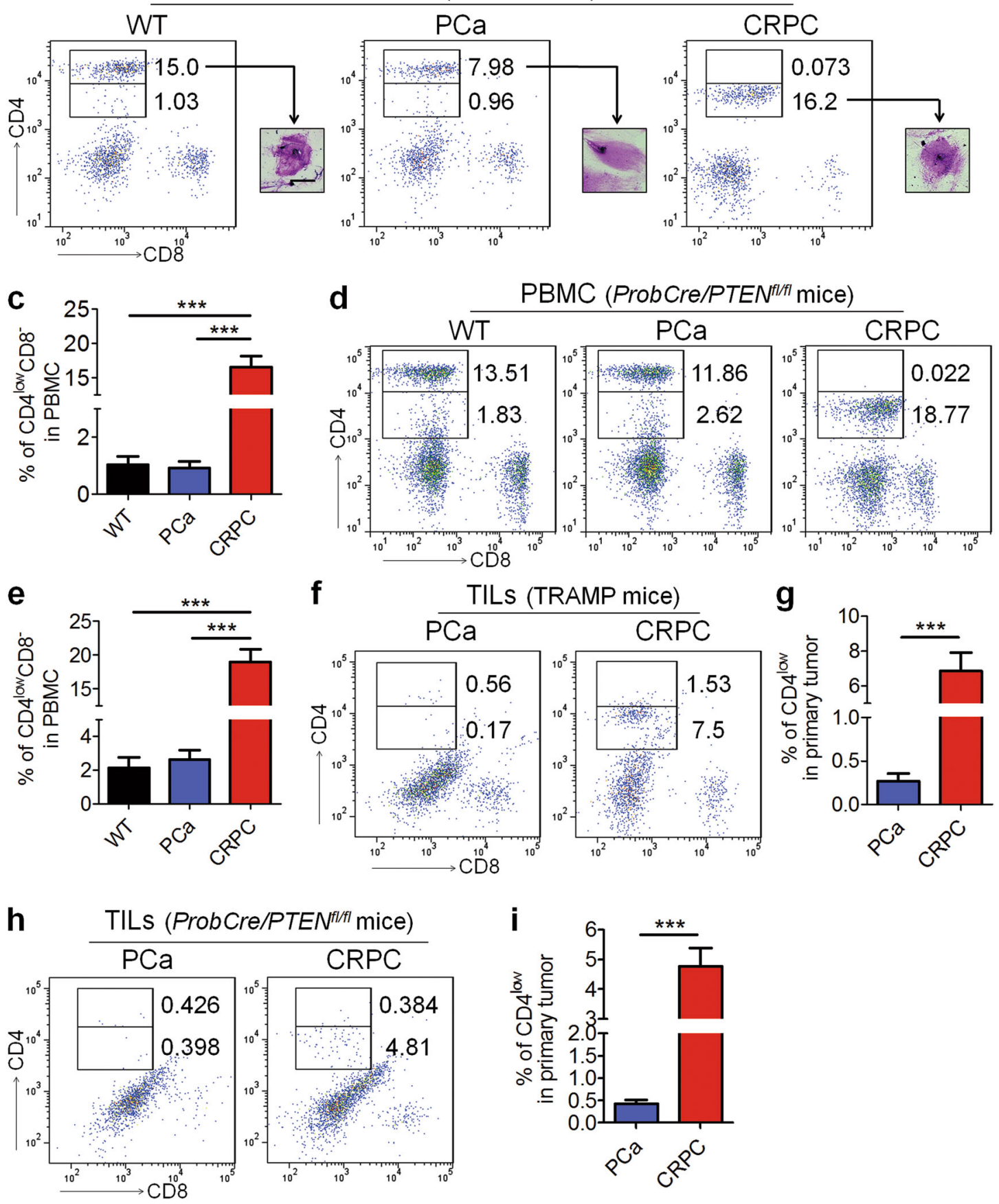

Fig. $2 \mathrm{CD}^{\text {low }} \mathrm{T}$ cells are produced in CRPC mouse models. a Experimental approach to construct CRPC mouse models. b CD4 ${ }^{\text {low }} \mathrm{T}$-cell frequencies in peripheral blood of CRPC TRAMP mice, sham-operation controls and WT mice (left). Morphology of CD4 ${ }^{+}$T cells by Wright stain (right). Scale bar, $5 \mu \mathrm{m}$. c Quantification of (b) $\left(n=5\right.$, every group). d, e CD4 $4^{\text {low }}$ T-cell frequencies in peripheral blood of CRPC ProbCre/Pten ${ }^{f / f}$ mice, sham-operation controls and WT mice ( $n=5$, every group). $\mathbf{f}, \mathbf{g}$ CD4 ${ }^{\text {low }}$ T-cell frequencies in primary tumor of CRPC TRAMP mice and sham-operation controls ( $n=5$, every group). $\mathbf{h}$, i CD4 ${ }^{\text {low }}$ T-cell frequencies in primary tumor of CRPC ProbCre/Pten ${ }^{f / f l}$ mice and sham-operation controls ( $n=5$, every group). Mean \pm SEM, ${ }^{* * *} P<0.001$ by $t$ tests $(\mathbf{c}, \mathbf{e}, \mathbf{g}, \mathbf{i})$ 
a

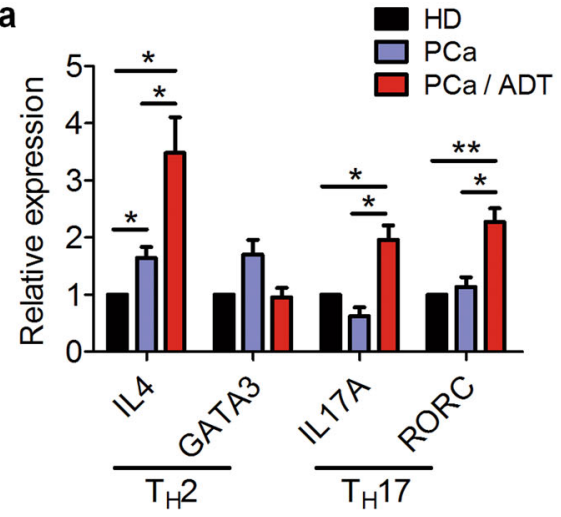

b

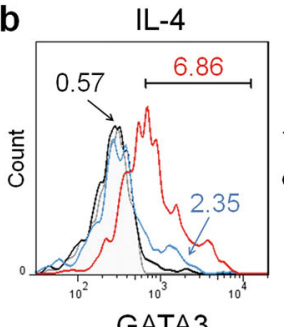

GATA3
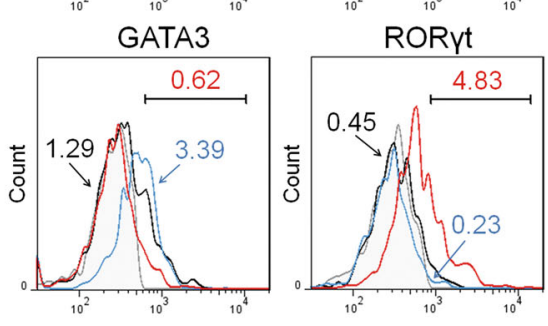

e

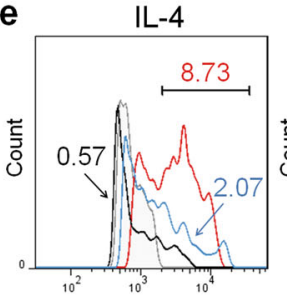

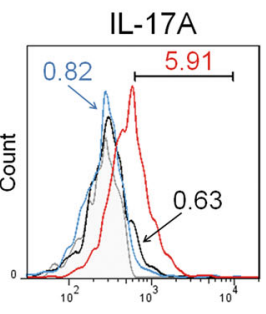

IL-17A

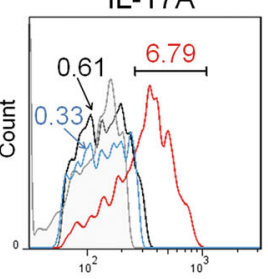

C
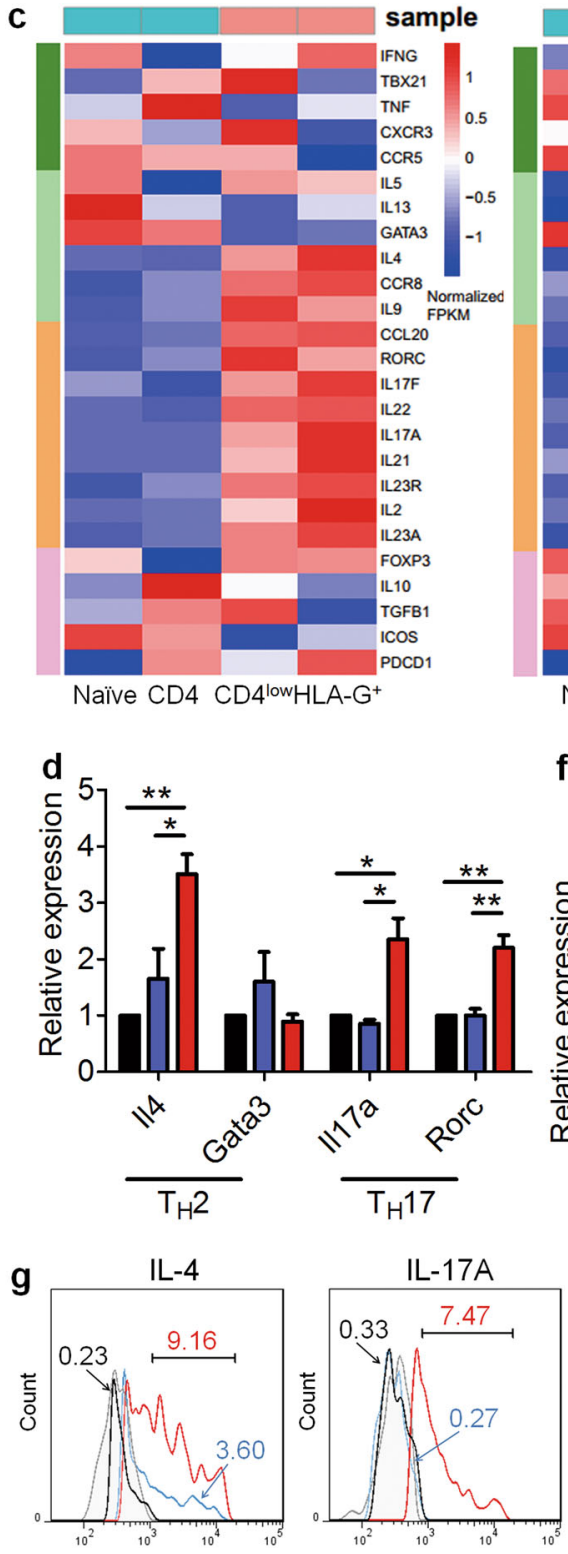

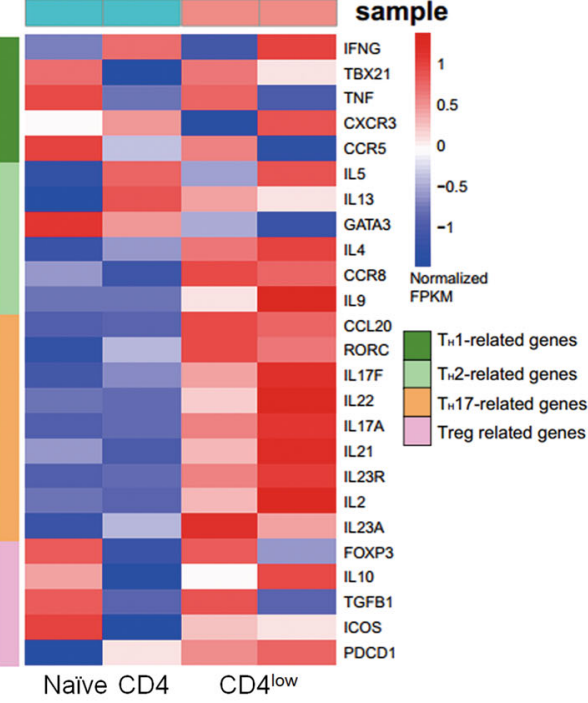

f
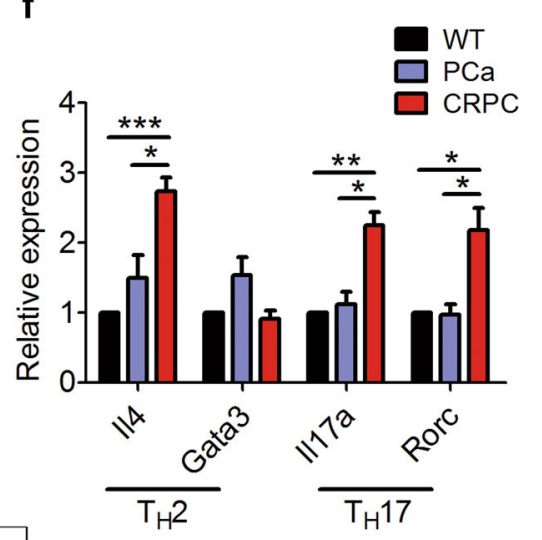

Fig. 3 CD4 ${ }^{\text {low }} \mathrm{HLA}-\mathrm{G}^{+} \mathrm{T}$ cells are IL-4-expressing $\mathrm{T}_{\mathrm{H}} 17$ cells. $\mathbf{a}, \mathbf{b} \mathrm{T}_{\mathrm{H}} 2$ - and $\mathrm{T}_{\mathrm{H}}$ 17-associated cytokine and transcriptional factor expression in peripheral blood CD4 ${ }^{+}$T cells from healthy donors (black line in (b)), PCa patients (blue line in (b)) and PCa/ADT patients (red line in (b)) by RTPCR (a) ( $n=5$, every group) and flow cytometry (b). $\mathbf{c}$ Heat map of expression of $\mathrm{T}_{\mathrm{H}} 1-, \mathrm{T}_{\mathrm{H}} 2-, \mathrm{T}_{\mathrm{H}}$ 17- and $\mathrm{T}_{\text {reg }}$-associated genes in CD4 ${ }^{\text {low }} \mathrm{HLA}-\mathrm{G}^{+}$ $T$ cells isolated from peripheral blood of PCa/ADT patients and human naive $\mathrm{CD}^{+}{ }^{+} \mathrm{T}$ cells derived from peripheral blood of healthy donors (left). Heat map of expression of $T_{H} 1-, T_{H} 2-, T_{H} 17$ - and $T_{\text {reg }}$-relevant genes in CD4 ${ }^{\text {low }} T$ cells isolated from peripheral blood of CRPC TRAMP mice and murine naïve $\mathrm{CD}^{+} \mathrm{T}$ cells derived from spleen of WT mice (right). $\mathbf{d} \mathrm{T}_{H} 2$ - and $\mathrm{T}_{H}$ 17-associated cytokine and transcriptional factor expression in peripheral blood CD4 ${ }^{+}$T cells from CRPC TRAMP mice, sham-operation controls and WT mice by RT-PCR ( $n=5$, every group). e $T_{H} 2$ - and $T_{H}$ 17-associated cytokine expression in peripheral blood CD4 ${ }^{+} T$ cells from CRPC TRAMP mice (red line), sham-operation controls (blue line) and WT mice (black line). $\mathrm{T}_{\mathrm{H}} 2$ - and $\mathrm{T}_{\mathrm{H}}$ 17-associated cytokine and transcriptional factor expression in peripheral blood CD4 ${ }^{+} \mathrm{T}$ cells from CRPC ProbCre/Pten ${ }^{A / f}$ mice, sham-operation controls and wild-type mice by RT-PCR ( $n=5$, every group). $\mathbf{g} \mathrm{T}_{\mathrm{H}} 2-$ and $\mathrm{T}_{\mathrm{H}} 17$-associated cytokine expression in peripheral blood CD4 ${ }^{+} \mathrm{T}$ cells from CRPC ProbCre/Pten ${ }^{\text {fl/fl }}$ mice (red line), sham-operation controls (blue line) and wildtype mice (black line). Mean SEM, ${ }^{*} P<0.05,{ }^{* *} P<0.01,{ }^{* * *} P<0.001$ by $t$ tests $(\mathbf{a}, \mathbf{d}, \mathbf{f})$

the control group (Supplementary information, Fig. S13a). This indicates that intratumoral $\mathrm{CD} 4{ }^{\mathrm{low}} \mathrm{HLA}-\mathrm{G}^{+} \mathrm{T}$ cells are similar to the population of $\mathrm{CD} 4{ }^{\text {low }} \mathrm{HLA}-\mathrm{G}^{+}$T cells in the peripheral blood, and both are IL-4-expressing $T_{H} 17$ cells. The results were also verified in PCa mouse models (Supplementary information, Fig. S13c, e). In addition, we also examined CD4 expression in CD4 ${ }^{\text {low }} \mathrm{HLA}-\mathrm{G}^{+}$ $T$ cells derived from the peripheral blood and primary tumors of PCa/ADT patients. The resulting RT-PCR data showed that the level of CD4 expression in intratumoral CD4 ${ }^{+} \mathrm{T}$ cells of the PCa/ADT group was significantly lower than that of the PCa group, although the difference in CD4 expression between these two groups was slightly decreased in the primary tumors, compared to that in the peripheral blood (Supplementary information, Fig. S13b) suggesting that $C D 4^{\text {low }}{ }^{\mathrm{HLA}-\mathrm{G}^{+}} \mathrm{T}$ cells may undergo some differentiation/ polarization in tumor tissues. These phenomena were also confirmed in PCa mouse models (Supplementary information, Fig. S13d, f). Taken together, the finding that both $\mathrm{CD}^{\text {low }} \mathrm{T}$ cells and $\mathrm{CD} 4{ }^{\text {low }} \mathrm{HLA}-\mathrm{G}^{+} \mathrm{T}$ cells are IL-4-expressing $\mathrm{T}_{\mathrm{H}} 17$ cells suggests that the $C D 4^{\text {low }} \mathrm{T}$ cells are indeed murine homologs of the CD4 ${ }^{\text {low }} \mathrm{HLA}-\mathrm{G}^{+} \mathrm{T}$ cells in humans. 
a

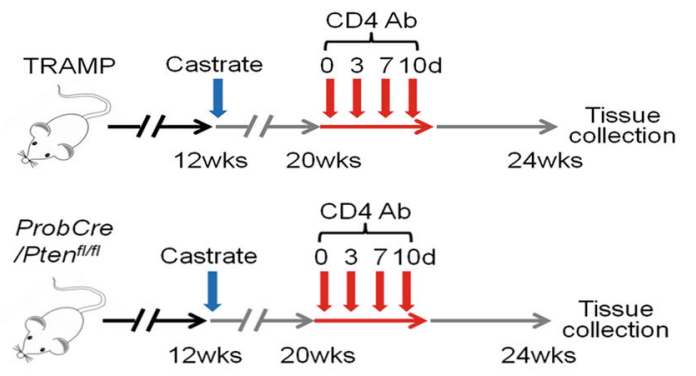

b
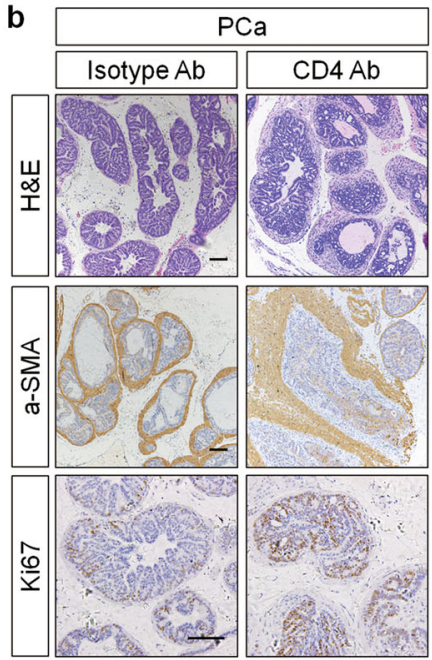

C
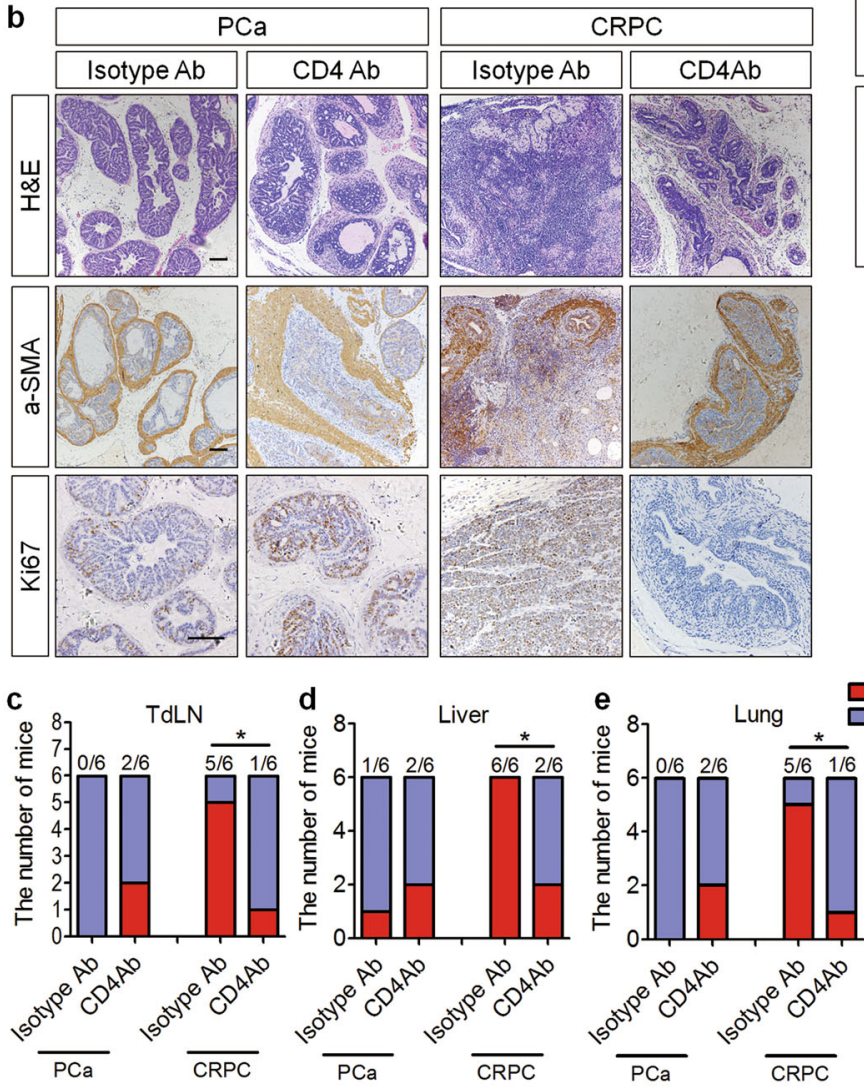

Metastasis

f
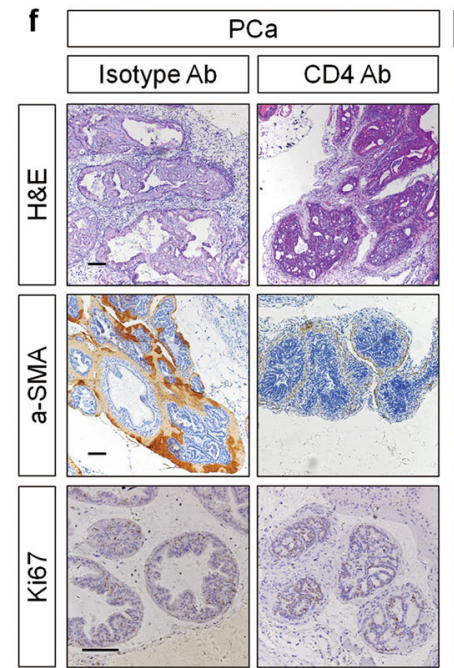

j

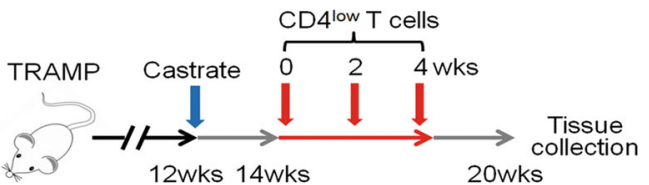

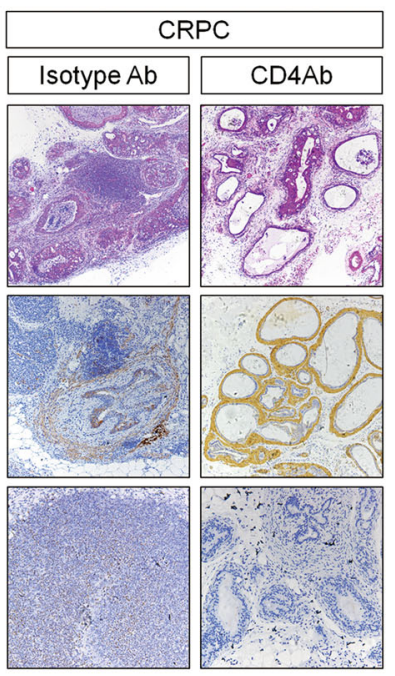

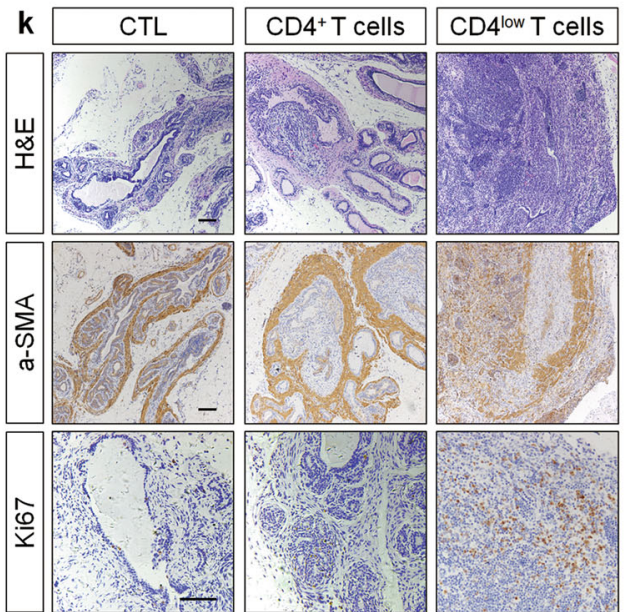

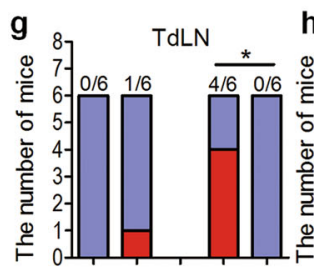
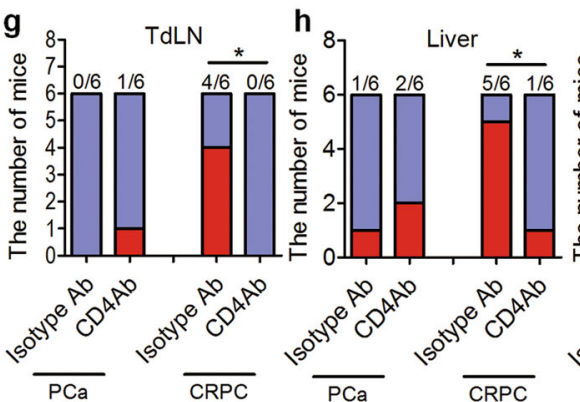
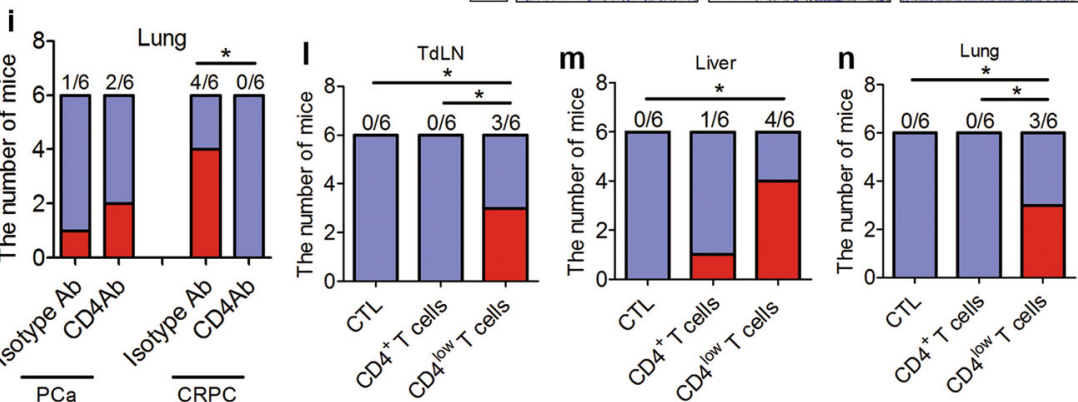

Fig. $4 \mathrm{CD}^{\text {low }} \mathrm{T}$ cells are essential for the formation of CRPC. a Experimental approach to block CD4 ${ }^{\text {low }} \mathrm{T}$ cells in castrated TRAMP and ProbCre/ Pten $^{f / f l}$ mice. wks, weeks. b H\&E and immunohistochemistry microscopy of prostate showing tumor progression in castrated TRAMP mice following CD4 ${ }^{\text {low }}$ T-cell depletion. Scale bar, $100 \mu \mathrm{m}$. c-e Incidence of TdLN (c), liver (d) and lung (e) metastasis following CD4 ${ }^{\text {low }}$ T-cell depletion in castrated TRAMP mice ( $n=6$, every group). $\mathrm{f} \mathrm{H \& E}$ and immunohistochemistry microscopy of prostate showing tumor progression in castrated ProbCre/Pten ${ }^{f / f}$ mice following CD4 ${ }^{\text {low }}$ T-cell depletion. Scale bar, $100 \mu \mathrm{m}$. g-i Incidence of TdLN (g), liver (h) and lung (i) metastasis following CD4 ${ }^{\text {low }}$ T-cell depletion in castrated ProbCre/Pten ${ }^{\text {fl/fl}}$ mice ( $n=6$, every group). j Experimental approach for adoptive transfer of CD4 ${ }^{\text {low }}$ T cells in castrated TRAMP mice. wks, weeks. $\mathbf{k}$ H\&E and immunohistochemistry microscopy of prostate showing tumor progression following adoptive transfer of CD4 ${ }^{\text {low }} \mathrm{T}$ cells. Scale bar, $100 \mu \mathrm{m}$. I-n Incidence of TdLN (I), liver (m) and lung (n) metastasis after adoptive transfer of $C D 4^{\text {low }} \mathrm{T}$ cells. ${ }^{*} P<0.05$ by $\chi^{2}$ test (c-e, $\mathbf{g - i}$, I-n) 
$\mathrm{CD} 4^{\text {low }} \mathrm{T}$ cells are essential for the occurrence of CRPC To investigate the role of CD4 ${ }^{\text {low }} T$ cells in the onset of CRPC, we used a CD4-neutralizing antibody to deplete CD4 ${ }^{\text {low }} T$ cells during carcinogenesis of castrated TRAMP mice. As our flow cytometric analysis showed that CD4 ${ }^{\text {low }} \mathrm{T}$ cells arise only at an early stage of CRPC formation (appearing at 8 weeks and disappearing at 16 weeks after castration; Supplementary information, Fig. S14), we injected anti-CD4 antibody every 3 days at 8 weeks after castration for a total of four times (Fig. 4a). This effectively depleted the $\mathrm{CD} 4{ }^{\text {low }}$ T-cell population (Supplementary information, Fig. S15a). Histopathological analysis revealed that, compared to the isotype antibody controls, depletion of $C D 4^{\text {low }} \mathrm{T}$ cells resulted in only high-grade prostatic intraepithelial neoplasia (PIN), but not invasive carcinomas (Fig. 4b; Supplementary information, Fig. S15b), and significantly reduced the incidence of TdLN, liver and lung metastasis in these mice (Fig. 4c-e; Supplementary information, Fig. S15c). Thus, these results showed that depletion of $\mathrm{CD} 4^{\text {low }} \mathrm{T}$ cells could effectively inhibit the occurrence of CRPC. In sharp contrast, depletion of $\mathrm{CD}^{+}{ }^{+} \mathrm{T}$ cells using this anti-CD4 antibody in TRAMP mice without castration displayed little adverse effects on the progression of prostate cancer (Fig. 4b-e; Supplementary information, Fig. S15b and c). These phenomena were also verified in the ProbCre/Pten ${ }^{f / f l}$ prostate cancer mouse model (Fig. 4f-i; Supplementary information, Fig. S16). Since there may have been off-target effects of this anti-CD4 antibody on other immune cells expressing CD4, we performed adoptive transfer of $C D 4^{\text {low }} \mathrm{T}$ cells into castrated TRAMP mice to confirm that these cells play a key role in CRPC onset. To this end, we intravenously injected $C D 4^{\text {low }} \mathrm{T}$ cells isolated from the peripheral blood of CRPC TRAMP mice into twoweek castrated TRAMP mice every 2 weeks for a total of three times (Fig. 4j) and confirmed the infiltration of CD4 ${ }^{\text {low }} \mathrm{T}$ cells into the tumor microenvironment (Supplementary information, Fig. S17a). Histopathological analyses showed that, compared to control groups, castrated TRAMP mice with adoptive transfer of $\mathrm{CD} 4^{\text {low }} \mathrm{T}$ cells developed more aggressive cancer (Fig. 4k; Supplementary information, Fig. S17b) and exhibited a significantly elevated incidence of tumor metastasis (Fig. 4I-n; Supplementary information, Fig. S17c). This indicates that CD4 ${ }^{\text {low }} \mathrm{T}$ cells can accelerate the formation of CRPC in castrated TRAMP mice. Collectively, these results demonstrate that $\mathrm{CD} 4^{\text {low }} \mathrm{T}$ cells are essential for the occurrence of CRPC.

$\mathrm{CD} 4^{\text {low }} \mathrm{T}$ cells induce androgen-independent growth of PCa by modulating the properties of tumor-associated macrophages Considering the essential role that $\mathrm{CD}^{+} \mathrm{T}_{\mathrm{H}} 2$ cells play in communicating with tumor-associated macrophages (TAMs) via IL-4 in the promotion of breast cancer metastasis, ${ }^{26,27}$ and that $\mathrm{CD}^{+} \mathrm{T}_{\mathrm{H}} 17$ cells and IL-17 pathogenically promote tumor progression by recruiting myeloid cells into the tumor microenvironment, ${ }^{28-30}$ we addressed the possibility that $\mathrm{CD} 4^{\text {low }} \mathrm{T}$ cells might modulate the properties of myeloid cells to induce the androgen-independent growth of prostate cancer cells. We found that the percentage of $C D 11 b^{\text {low }} F 4 / 80^{\text {hi }}$ and $C D 11 b^{\text {hi }} F 4 / 80^{\text {low }}$ myeloid cells was increased in CRPC TRAMP mice, as compared with sham-operation controls (Fig. 5a-c). However, following the
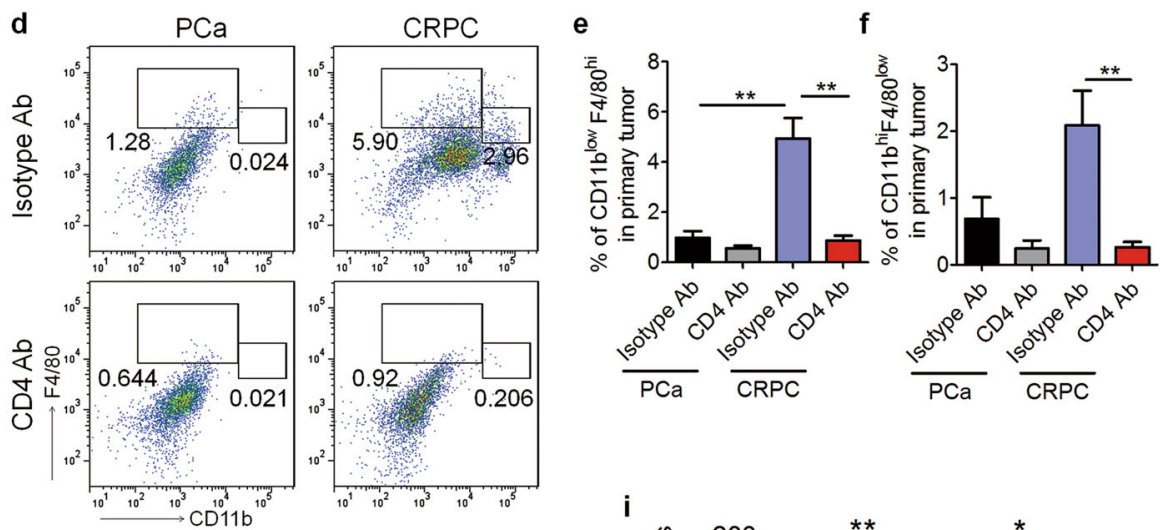
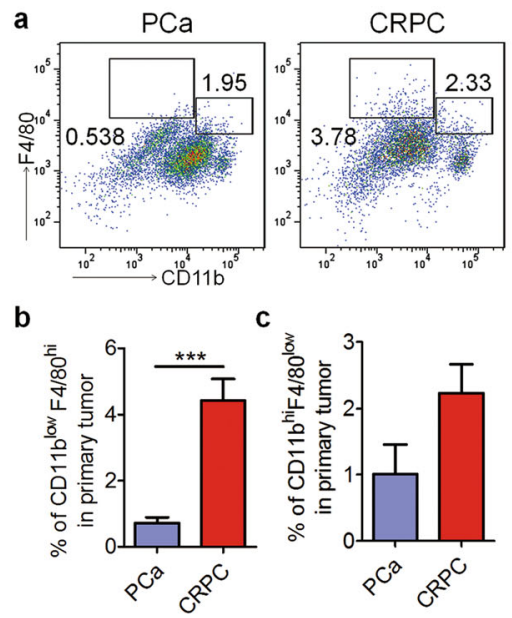

a

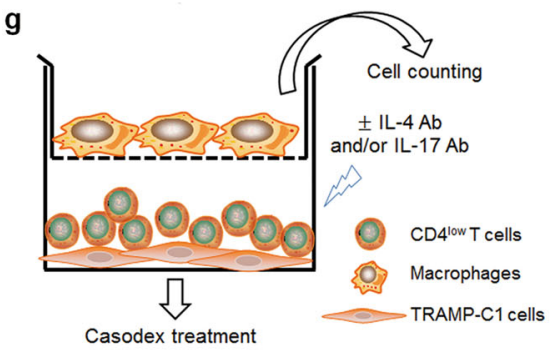

h

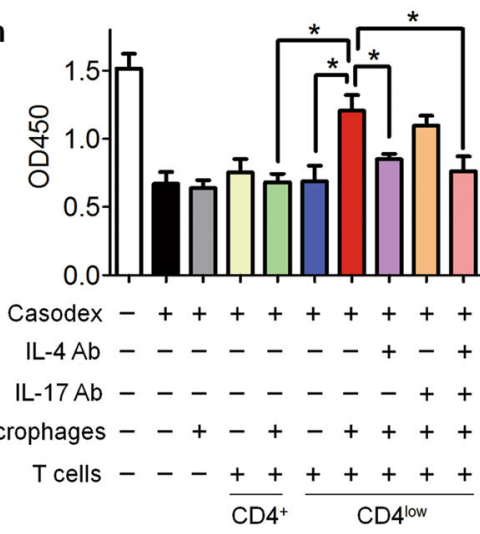

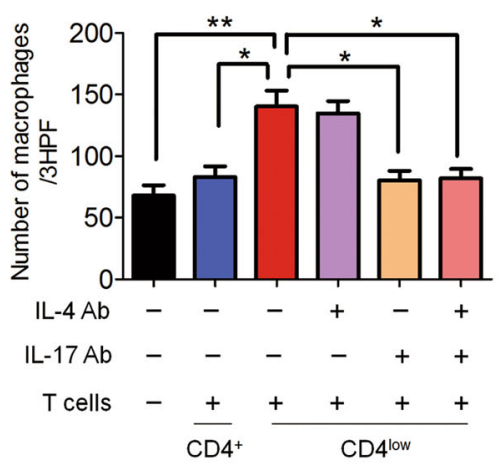

Fig. $5 \mathrm{CD}^{\text {low }} \mathrm{T}$ cells induce androgen-independent growth of PCa cells by modulating the properties of TAMs. a CD11 $\mathrm{b}^{\text {low }} \mathrm{F} 4 / 80^{\text {hi }}$ and $\mathrm{CD} 11 \mathrm{~b}^{\text {hi }} \mathrm{F} 4 / 80^{\text {low }}$ TAM frequencies in primary tumor of CRPC TRAMP mice and sham-operation controls. b, $\mathbf{c}$ Quantification of $(\mathbf{a})(n=6$, every

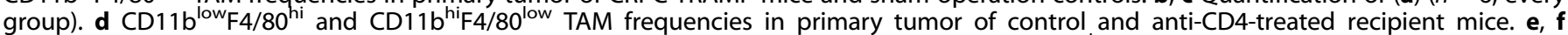
Quantification of (d) $\left(n=6\right.$, every group). $\mathbf{g}$ Experimental approach to evaluate the roles of CD4 ${ }^{\text {low }}$ T cells in modulating the properties of TAMs to promote androgen-independent growth of PCa cells. $\mathbf{h}$ Cell proliferation of TRAMP-C1 cells treated with $20 \mu \mathrm{M}$ Casodex in the cocultures as in ( $\mathbf{g})$ by CCK8 assay ( $n=3$, every group). $\mathbf{i}$ Quantification of the number of macrophages that have migrated through the membrane of insert in the co-cultures as in $(\mathbf{g})\left(n=3\right.$, every group). Mean $\pm \mathrm{SEM},{ }^{*} P<0.05,{ }^{* *} P<0.01,{ }^{* * *} P<0.001$ by $t$ tests $(\mathbf{b}, \mathbf{c}, \mathbf{e}, \mathbf{f}, \mathbf{h}, \mathbf{i})$ 
1110

depletion of $\mathrm{CD} 4^{\text {low }} \mathrm{T}$ cells in the castrated TRAMP mice by treatment with anti-CD4 antibody, the two myeloid cell subsets essentially disappeared (Fig. $5 d-f$ ). In addition, previous studies reported that two subsets of TAMs, marked as $C D 11 b^{\text {low }} \mathrm{F} 4 / 80^{\text {hi }}$ and $C D 11 b^{\text {hi }} F 4 / 80^{\text {low }}$, could be distinguished in murine mammary and pulmonary tumors 31,32 and more importantly our flow cytometric data showed that neither of the two myeloid cell subsets expressed $\mathrm{Gr}-1$, indicating that these cells are TAMs but not MDSCs $\left(\mathrm{CD} 11 \mathrm{~b}^{+} \mathrm{Gr}-1^{+}\right)$(Supplementary information, Fig. S18a). Together, this implies that CD4 ${ }^{\text {low }} \mathrm{T}$ cells might affect the activity and/or accumulation of TAMs in castrated TRAMP mice. Notably, the increase of $C D 11 b^{\text {hi }} 44 / 80^{\text {low }}$ TAMs in the primary tumors of CRPC TRAMP mice was not statistically significant (Fig. $5 \mathrm{C}$ ), suggesting that $\mathrm{CD} 4^{\text {low }} \mathrm{T}$ cells may mainly modulate the properties of $C D 11 b^{\text {low }} F 4 / 80^{\text {hi }}$ TAMs. To further confirm the positive effects of $C D 4^{\text {low }} \mathrm{T}$ cells in modulating the pro-tumorigenic activities of TAMs, we established an in vitro coculture system with $\mathrm{CD} 4^{\text {low }} \mathrm{T}$ cells, bone marrow-derived macrophages and TRAMP-C1 cells, the last of which are androgen-dependent prostate tumor cells derived from TRAMP mice $^{33}$ (Fig. $5 \mathrm{~g}$ ). We found that, in the presence of macrophages, $C D 4^{\text {low }} T$ cells had higher ability to induce androgen-independent growth of TRAMP-C1 cells than $\mathrm{CD}^{+}{ }^{+} \mathrm{T}$ cells (Fig. 5h). Notably, $\mathrm{CD} 4^{\text {low }} \mathrm{T}$ cells or macrophages alone did not exhibit an ability to induce androgen-independent growth of TRAMP-C1 cells (Fig. 5h). To further investigate the effects of $\mathrm{CD} 4^{\text {low }} \mathrm{T}$ cells on the polarization of TAMs, macrophages were collected from the coculture system and examined by flow cytometry. We found a significant increase in CD206 (M2 macrophages) but not CD80 (M1 macrophages) expression in $\mathrm{CD} 4^{\text {low }} \mathrm{T}$-macrophage co-cultures, compared to those in $\mathrm{CD}^{+}{ }^{+} \mathrm{T}$-macrophage co-cultures (Supplementary information, Fig. S18b). This suggests that CD4 ${ }^{\text {low }} \mathrm{T}$ cells induce M2 polarization of macrophages. We then measured the number of macrophages that had migrated through the membranous insert in the co-culture system. We found that a greater number of cells migrated in the CD4 ${ }^{\text {low }} \mathrm{T}$-macrophage cocultures than in the $\mathrm{CD}^{+} \mathrm{T}$-macrophage co-cultures (Fig. 5i). Taken together, these findings indicate that $\mathrm{CD} 4{ }^{\text {low }} \mathrm{T}$ cells promote androgen-independent growth of prostate cancer cells by modulating the activities and accumulation of macrophages.

To further explore the mechanism by which $C D 4^{\text {low }} \mathrm{T}$ cells modulate the properties of macrophages, IL-4 and/or IL-17 neutralizing antibodies were added into the co-culture system (Fig. $5 \mathrm{~g}$ ). This revealed that neutralization of IL-4, but not IL-17, completely abrogated the androgen-independent growth of TRAMP-C1 cells (Fig. 5h) and M2 polarization of macrophages in the co-culture system (Supplementary information, Fig. S18b). In contrast, antibody blockage of IL-17 inhibited the migration of macrophages in the co-culture system (Fig. 5i). Thus, CD4 ${ }^{\text {low }} \mathrm{T}$ cells regulate the activities and migration of TAMs by IL- 4 and IL-17 to promote androgen-independent growth of prostate cancer cells.

$\mathrm{PGE}_{2}$-EP2 signaling promotes the differentiation and polarization of $\mathrm{CD} 4^{\text {low }} \mathrm{T}$ cells

To explore the mechanism responsible for production of $C D 4^{\text {low }}$ $\mathrm{T}$ cells, $\mathrm{CD}^{+} \mathrm{T}$ cells in the peripheral (TdLN and spleen) and central (thymus) lymphoid organs of CRPC TRAMP mice were analyzed by flow cytometry. The proportion of $\mathrm{CD} 4^{\text {low }} T$ cells was dramatically increased in the peripheral lymphoid organs (Supplementary information, Fig. S19a) whereas aberrant CD4 ${ }^{\text {low }} C D 8$ and $\mathrm{CD} 4{ }^{\text {low }} \mathrm{CD} 8{ }^{\text {low }}$ cells accumulated in the thymuses of CRPC mice compared to controls (Fig. 6a; Supplementary information, Fig. S19b). Furthermore, we found that $\mathrm{CD} 4^{\text {low }} \mathrm{CD} 88^{\text {low }}$ and CD4 ${ }^{\text {low } C D 8}$ cells began to appear at 8 weeks and disappeared at 16 weeks after castration (Supplementary information, Fig. S19c). This is similar to the times at which the CD4 ${ }^{\text {low }} \mathrm{T}$ cells appeared and disappeared in the peripheral blood (Supplementary information, Fig. S14). These results indicate that anomalous differentiation of thymocytes contributes to the generation of $\mathrm{CD} 4^{\text {low }} \mathrm{T}$ cells in CRPC mice. These phenomena were also confirmed in the ProbCre/Pten ${ }^{\text {fl/fl }}$ prostate cancer mouse model (Fig. 6b; Supplementary information, Fig. S19d).

To determine whether the aberrant differentiation of thymocytes was induced by an androgen blockade alone, the frequencies of $\mathrm{CD} 4{ }^{\text {low }} \mathrm{CD} 88^{\text {low }}$ and $\mathrm{CD} 4{ }^{\text {low }} \mathrm{CD} 8^{-}$thymocytes in castrated control wild-type mice were examined by flow cytometry. The results showed that there was no significant difference in the percentages of these cells between castrated and sham-operation control groups (Supplementary information, Fig. S20a). Moreover, CD4 ${ }^{\text {low }} \mathrm{T}$ cells also did not expand in peripheral blood of castrated control wild-type mice (Supplementary information, Fig. S20b). Together, these results indicate that an androgen blockade alone does not induce the anomalous differentiation of thymocytes in CRPC mice. Several biochemical signals have been shown to play roles in thymocyte differentiation. ${ }^{34-36}$ In particular, prostaglandin $E_{2}\left(P_{G E}\right)$ has been demonstrated to induce $\mathrm{CD}^{-} \mathrm{CD} 8^{-}$double negative (DN) cells to differentiate into $C D 4^{\text {low }} C D 8^{\text {low }}$ cells in vitro. ${ }^{37}$ We therefore investigated the role of $\mathrm{PGE}_{2}$ in this unusual thymocyte differentiation. First, we examined if the synthesis of $\mathrm{PGE}_{2}$ was upregulated following ADT in these mice and in PCa patients. We found that $P G E_{2}$ levels were substantially increased in the serum of CRPC TRAMP and ProbCre/Pten ${ }^{f / f l}$ mice and PCa/ADT patients (Fig. 6c-e). Secondly, we determined whether $\mathrm{PGE}_{2}$ exerted a direct role in thymocyte differentiation. $\mathrm{CD}^{-} \mathrm{CD} 8^{-} \mathrm{DN}$ cells isolated from the thymuses of wild-type mice were induced to develop into mature $T$ cells in the presence of autologous thymic stromal cells and IL-7 for 5 days in culture, into which different concentrations of $\mathrm{PGE}_{2}$ were added. $\mathrm{PGE}_{2}$ promoted the accumulation of $\mathrm{CD} 4{ }^{\text {low }} \mathrm{CD} 88^{\text {low }}$ and $\mathrm{CD} 44^{\text {low }} \mathrm{CD} 8^{-}$cells in a dosedependent manner, implying that $\mathrm{PGE}_{2}$ might indeed contribute to the abnormal differentiation of thymocytes in CRPC mice (Fig. 6f; Supplementary information, Fig. S21a and b). It has been demonstrated that EP2 and EP4 are major $\mathrm{PGE}_{2}$ receptors in T cells. ${ }^{38}$ Furthermore, our results showed that the transcriptional level of EP2 but not EP4 was dramatically increased in thymocytes of CRPC mice (Fig. $6 \mathrm{~g}$ ). To determine which receptor(s) primarily mediates $\mathrm{PGE}_{2}$-induced, aberrant $\mathrm{T}$ cell differentiation, we examined the effects of adding an EP2 antagonist (AH6809) and/or EP4 antagonist (GW627368X) into the culture system described above. We found that the EP2 antagonist significantly inhibited the effect of $\mathrm{PGE}_{2}$ on $\mathrm{T}$ cell differentiation; the EP4 antagonist had a synergistic function when applied together with EP2 antagonist; whereas the EP4 antagonist alone was ineffective (Fig. 6f; Supplementary information, Fig. S21a and b).

Consistent with a defect in thymocyte differentiation, the naïve $\mathrm{CD}^{+} \mathrm{T}$ cells also exhibited an unusual phenotype of $\mathrm{CD}^{\text {low }}{ }^{\mathrm{CD}} 62 \mathrm{~L}^{+}$in the CRPC mice (Fig. 6h; Supplementary information, Fig. S21c). To explore possible effects of $\mathrm{PGE}_{2}$ on the polarization of $\mathrm{CD}^{+}{ }^{+} \mathrm{T}$ cells, naïve $\mathrm{CD} 4^{+} \mathrm{T}$ cells were isolated from spleens of TRAMP and CRPC mice and were induced under $\mathrm{T}_{\mathrm{H}}$ 2-polarizing conditions as previously reported. ${ }^{26}$ This has been showed to mimic the in vivo environment in PCa (Fig. 3a, b, d-g; Supplementary information, Figs. S9c, e and S12a-c). Indeed, $\mathrm{PGE}_{2}$ polarized $\mathrm{CD} 4{ }^{\text {low }}$ naive $\mathrm{T}$ cells into IL- $4^{+} \mathrm{IL}-17 \mathrm{~A}^{+} \mathrm{CD} 4^{+} \mathrm{T}$ cells under $\mathrm{T}_{\mathrm{H}}$ 2-polarizing conditions, although almost half of the cells were still IL-4 ${ }^{+} \mathrm{IL}-17 \mathrm{~A}^{-} \mathrm{CD} 4^{+}\left(\mathrm{T}_{\mathrm{H}} 2\right)$ (Fig. 6i; Supplementary information, Fig. S21d-f). A recent study reported that $\mathrm{PGE}_{2}$ could up-regulate IL1R1 and IL23R expression in CD4 ${ }^{+} \mathrm{T}$ cells to promote $\mathrm{T}_{\mathrm{H}} 17$ cell differentiation. ${ }^{38}$ Using RT-PCR, we found that IL23R expression was dramatically enhanced along with $T$ cell polarization by $\mathrm{PGE}_{2}$ under the $T_{H}$ 2-polarizing conditions (Fig. 6j). Moreover, in the presence of IL-23, $\mathrm{PGE}_{2}$ significantly enhanced the proportion of IL-4 ${ }^{+} \mathrm{IL}-17 \mathrm{~A}^{+} \mathrm{CD}^{+} \mathrm{T}$ cells induced from $\mathrm{CD} 4^{\text {low }}$ naive $\mathrm{T}$ cells whereas IL-23 alone had no effect on this polarization (Fig. 6i; Supplementary information, Fig. S21e, f). To explore which 

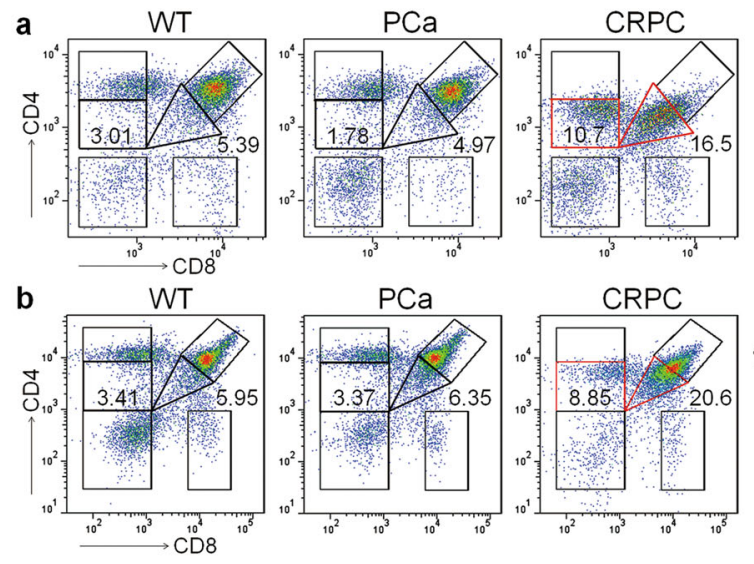

g

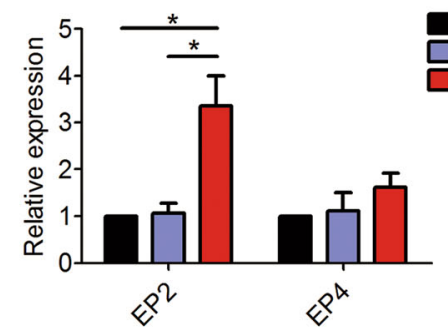

WT

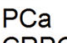

CRPC
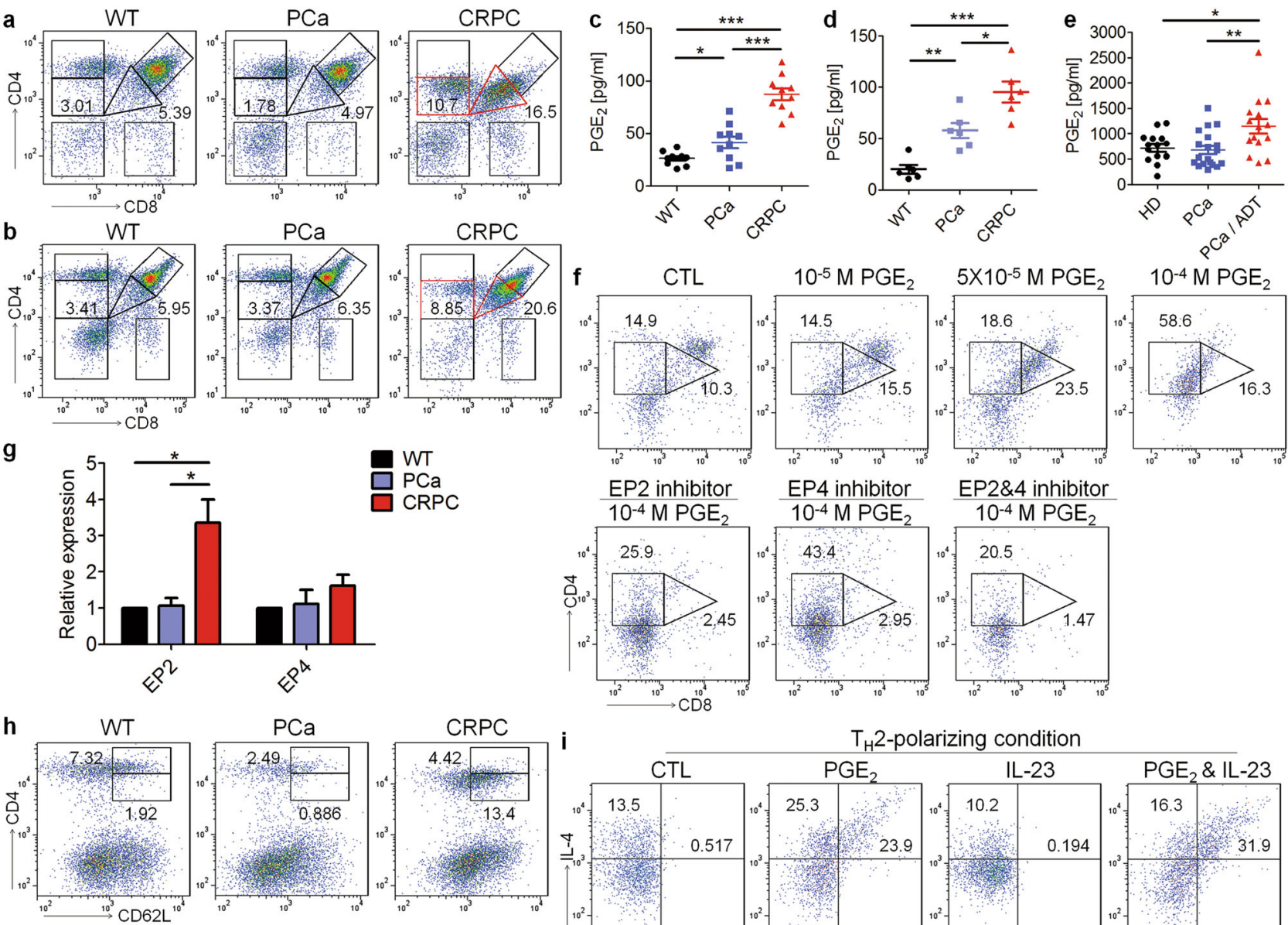

EP2 inhibitor

EP4 inhibitor $10^{-4} \mathrm{M} \mathrm{PGE}_{2}$

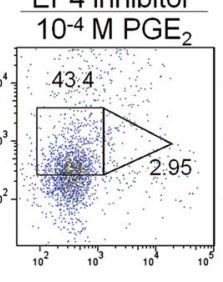

EP2\&4 inhibitor $10^{-4} \mathrm{M} \mathrm{PGE}_{2}$
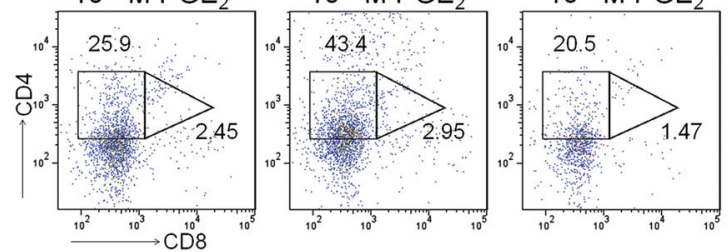

$\mathrm{T}_{\mathrm{H}}$ 2-polarizing condition

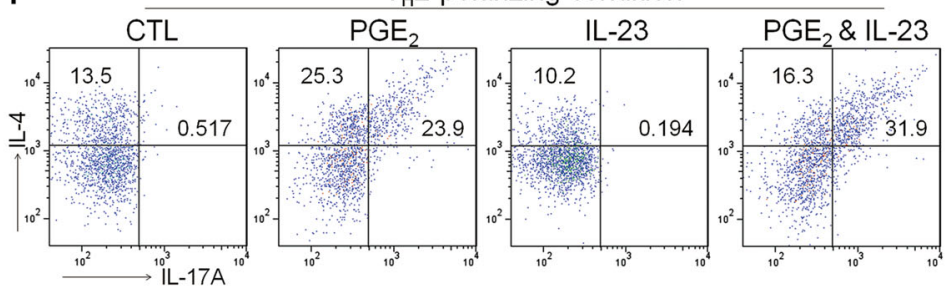

j

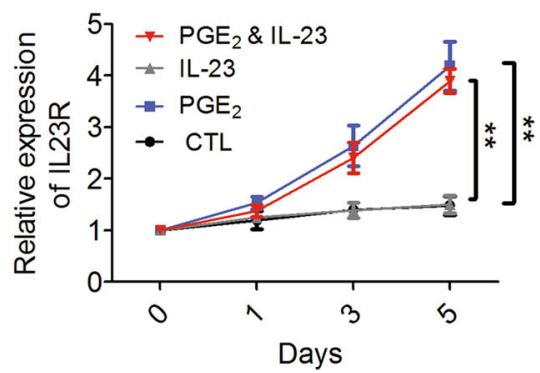

$\mathbf{k}$

$T_{\mathrm{H}}$ 2-polarizing condition+PGE ${ }_{2}$ \& IL-23

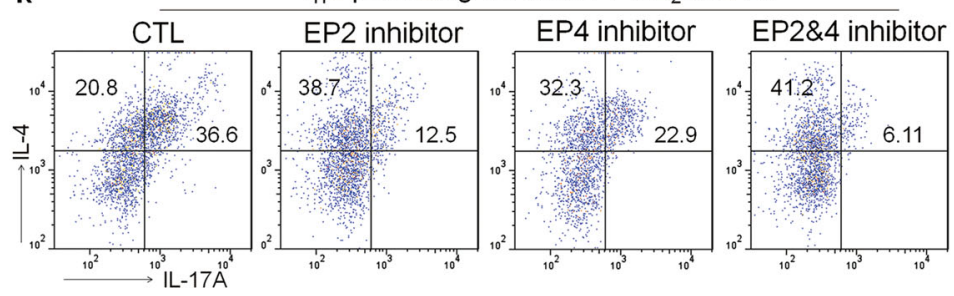

Fig. 6 The formation of $C D 4^{\text {low }} T$ cells is induced from $D N$ thymocytes via $P G E_{2}-E P 2$ signaling after castration. a, b $C D 4^{\text {low }} C D 8^{\text {low }}$ and

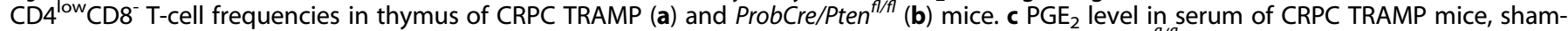

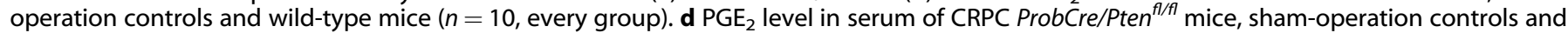
wild-type mice ( $n=6$, every group). e PGE 2 level in serum of healthy donors $(n=15)$, PCa patients $(n=19)$ and PCa/ADT patients $(n=15)$. $\mathbf{F}$ Percentage of $\mathrm{CD} 4{ }^{\text {low }} \mathrm{CD} 8{ }^{\mathrm{low}}$ and $\mathrm{CD} 4{ }^{\mathrm{low}} \mathrm{CD} 8^{-} \mathrm{T}$ cells in DN-thymocyte cultures in the presence of PGE 2 at different concentrations with/ without EP2 and/or EP4 antagonists. g EP2 and EP4 expression in CD4 ${ }^{+} \mathrm{CD} 8^{+}$thymocytes by RT-PCR $\left(n=5\right.$, every group). $\mathbf{h}$ CD4 ${ }^{\text {low }} \mathrm{CD6} 2 \mathrm{~L}^{+}$ naive CD4 T-cell frequencies in spleen of CRPC TRAMP mice. $\mathbf{i}$ IL-4 and IL-17A expression in naive CD4 ${ }^{\text {low }}$ T cells from spleen of CRPC TRAMP mice cultured under $\mathrm{T}_{\mathrm{H}}$ 2-polarizing conditions in the presence of $\mathrm{PGE}_{2}$ and/or IL-23 by flow cytometry. $\mathbf{j}$ IL23R expression during naïve CD4 ${ }^{\text {low }}$ T-cell polarization cultured as in (i) by RT-PCR ( $n=3$, every group). $\mathbf{k}$ IL-4 and IL-17A expression in naïve CD4 ${ }^{\text {low }}$ T cells from spleen of CRPC TRAMP mice cultured as in (i) with/without EP2 and/or EP4 antagonists. Mean \pm SEM, ${ }^{*} P<0.05$, ${ }^{* *} P<0.01,{ }^{* *} P<0.001$ by $t$ tests (c-e, g, j)

receptor(s) of $\mathrm{PGE}_{2}$ play a dominant role in the regulation of this polarization, EP2 and/or EP4 antagonists were added into the culture system described above. We found that the EP2 antagonist significantly decreased the proportion of $\mathrm{IL}-4^{+} \mathrm{IL}-17 \mathrm{~A}^{+} \mathrm{CD} 4^{+} \mathrm{T}$ cells polarized from naïve $\mathrm{CD} 4^{\text {low }} \mathrm{T}$ cells whereas the EP4 antagonist enhanced the inhibition of $\mathrm{T}$ cell polarization into IL-4 ${ }^{+} \mathrm{T}_{\mathrm{H}} 17$ cells when used together with EP2 antagonist, although the EP4 antagonist alone had no effect (Fig. 6k; Supplementary information, Fig. S21g, h). Together, these findings demonstrated that $\mathrm{PGE}_{2}$ induces the abnormal differentiation of thymocytes and promotes the polarization of naïve $\mathrm{CD} 4^{\text {low }} \mathrm{T}$ cells into $\mathrm{IL}-4^{+} \mathrm{IL}-$
$17 \mathrm{~A}^{+} \mathrm{CD}^{+} \mathrm{T}$ cells by activating $\mathrm{PGE}_{2}$-EP2 signaling and upregulating IL23R expression (Supplementary information, Fig. S22).

Celecoxib abrogates CRPC by inhibiting the generation of $C D 4^{\text {low }}$ T cells

Next, we determined whether depletion of $\mathrm{CD} 4^{\text {low }} \mathrm{T}$ cells by suppressing $\mathrm{PGE}_{2}$ signaling was able to inhibit occurrence of CRPC. Nonsteroidal anti-inflammatory drugs (NSAIDs), such as celecoxib and aspirin, can inhibit $\mathrm{PGE}_{2}$ synthesis by suppressing the activity of COX-2. ${ }^{39,40}$ There is also evidence suggesting that NSAIDs have chemo-preventive roles in colon cancer and PCa. ${ }^{39-43}$ 
a

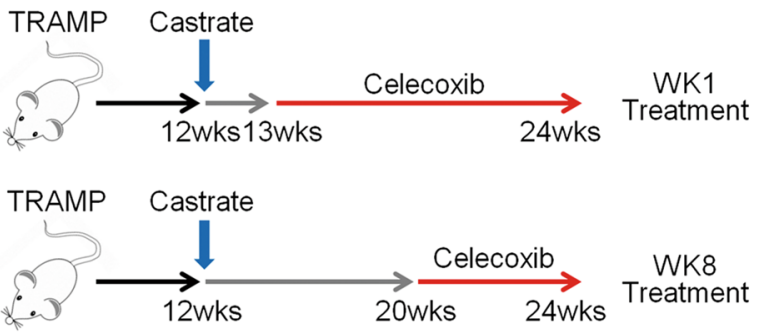

b
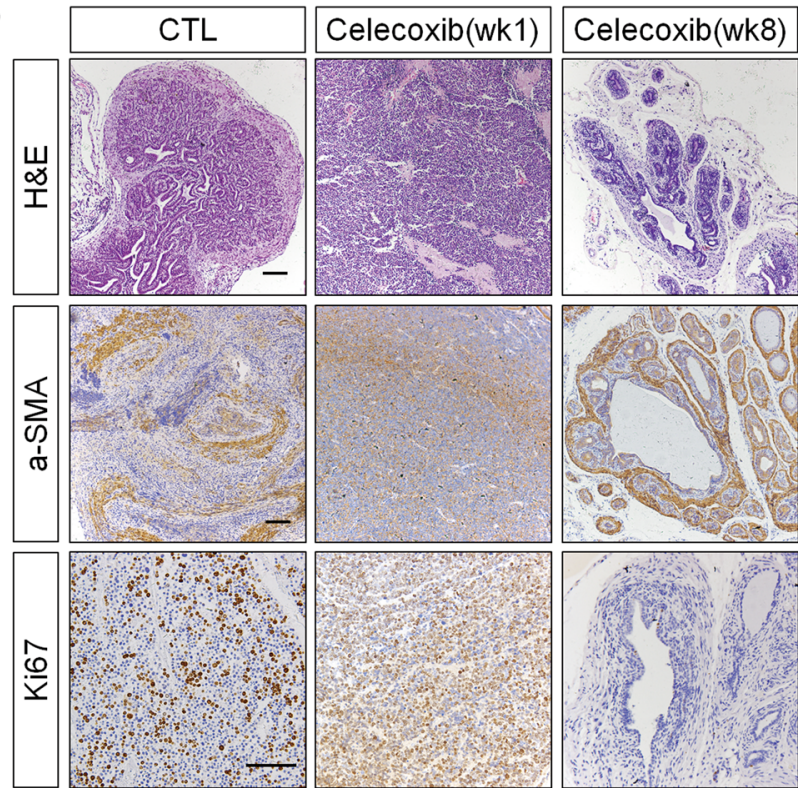

g
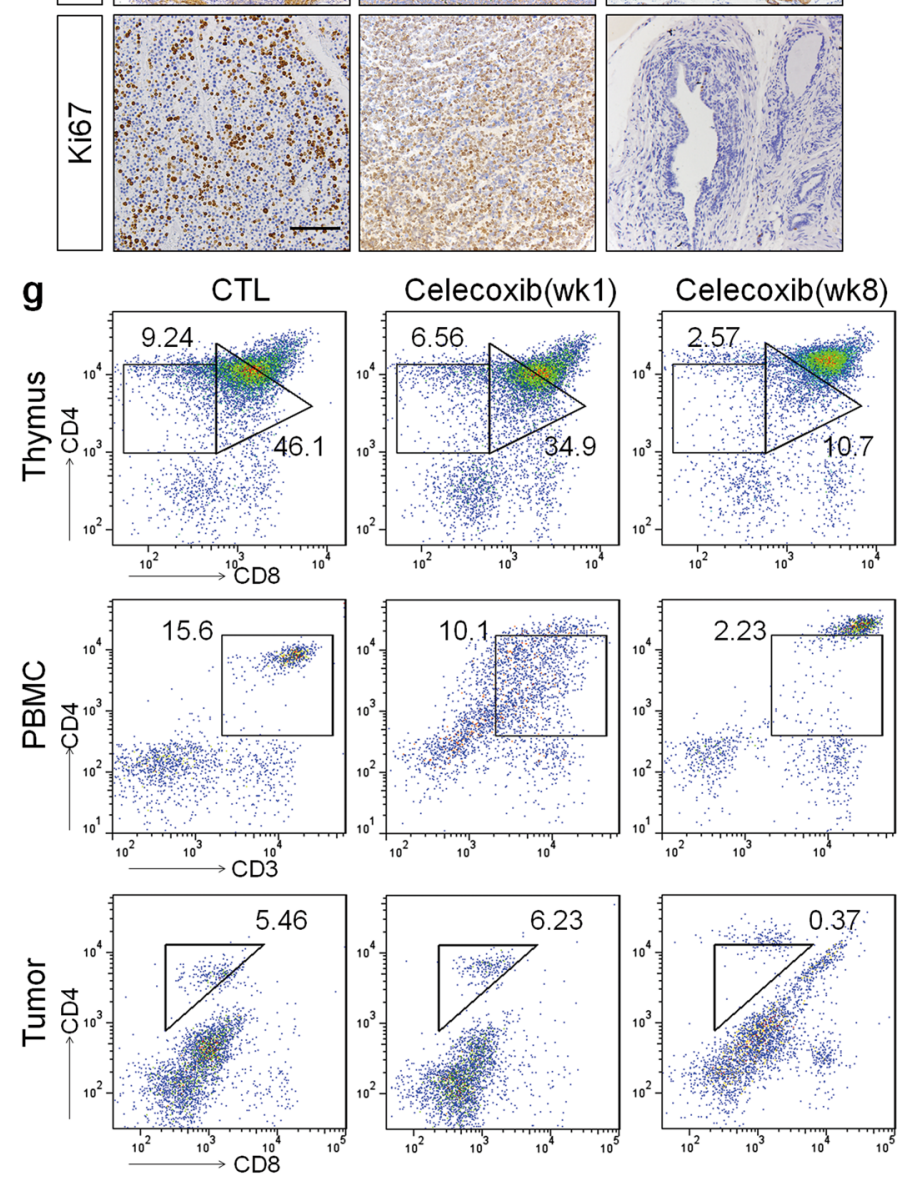
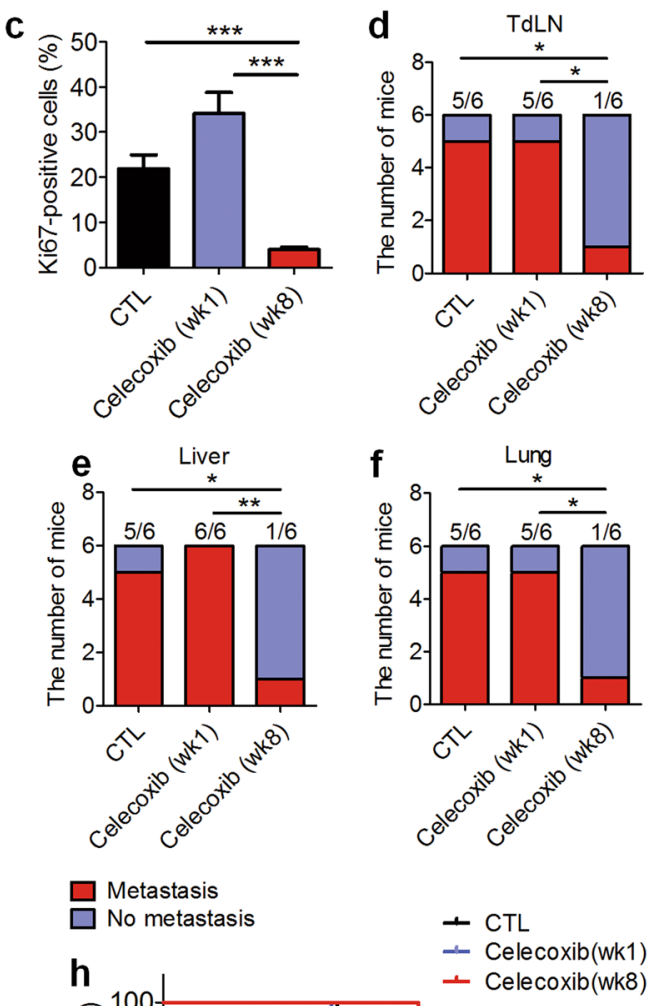

$+\mathrm{CTL}$

- Celecoxib(wk1) - Celecoxib(wk8)

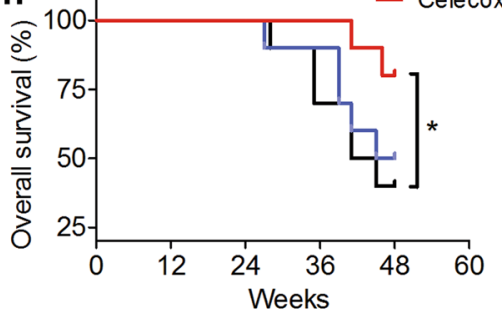

i
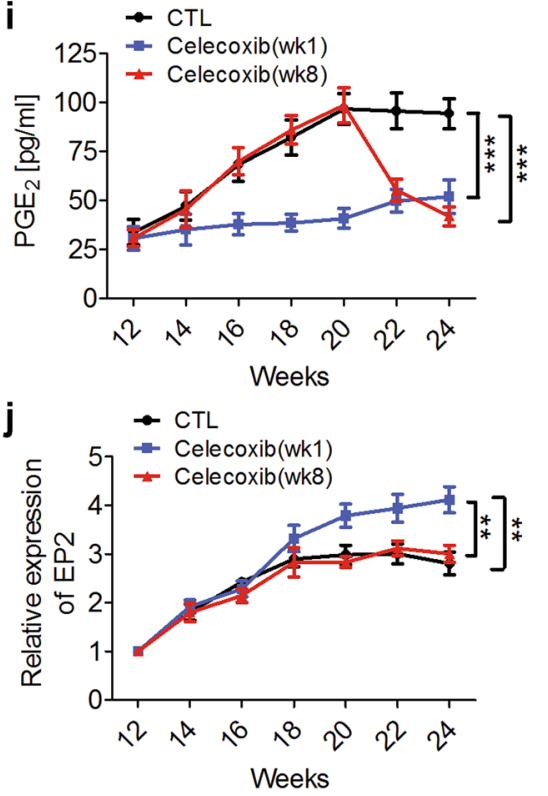

However, a recent clinical trial demonstrated that administration of celecoxib $400 \mathrm{mg}$ twice daily for up to 1 year is ineffective for high-risk PCa patients initiating ADT. ${ }^{44}$ We thus wondered whether blocking the synthesis of $\mathrm{PGE}_{2}$ at around 8 weeks after castration, when $C D 4^{\text {low }} T$ cells begin to appear in the thymus, would produce any beneficial effects in PCa treatment (Fig. 7a). Pathological analysis revealed that celecoxib treatment starting at 8 weeks after castration (celecoxib ${ }^{\text {Week }}{ }^{8}$ ) led to only high-grade PIN and a decreased number of proliferative cells (Fig. 7b, c), with no invasive carcinomas and a dramatically reduced incidence of 
Fig. 7 Celecoxib abrogates progressive development of CRPC by inhibiting the generation of CD4 ${ }^{\text {low }}$ T cells. a Experimental approach to evaluate the curative effect of celecoxib treatment on prostate cancer after ADT. wks, weeks. b H\&E and immunohistochemistry microscopy of prostate showing tumor progression following drug treatment as in (a). Scale bar, $100 \mu \mathrm{m}$. c Quantification of Ki67 staining in the prostate gland (means of $10 \mathrm{HPF} \pm \mathrm{SEM})$ for week 1 , week 8 drug-treated and control subgroups $(n=6$, every group). d-f Incidence of TdLN (d), liver (e) and lung (f) metastasis following drug treatment as in (a) $\left(n=6\right.$, every group). $\mathbf{g}$ CD $4^{\text {low }} \mathrm{CD} 8^{\text {low }}$ and $\mathrm{CD} 4^{\text {low }} \mathrm{CD} 8^{-}$thymocyte frequencies and CD4 ${ }^{\text {low }}$ T-cell frequencies in peripheral blood and primary tumors of castrated TRAMP mice following drug treatment as in (a). $\mathbf{h}$ Overall survival of week 1 , week 8 drug-treated and control subgroups $\left(n=10\right.$, every group). The endpoint of survival analysis is 48 weeks. $\mathbf{i}$, $\mathbf{j}$ PGE $E_{2}$ level in serum (i) and EP2 expression in peripheral blood CD4 ${ }^{+}$T cells (j) following drug treatment as in (a) $(n=5$, every group). Mean \pm SEM (c, $\mathbf{i}, \mathbf{j}) .{ }^{*} P<0.05,{ }^{* *} P<0.01,{ }^{* *} P<0.001$ by $t$ tests $(\mathbf{c}, \mathbf{i}, \mathbf{j}), \chi^{2}$ test (d-f) and log-rank analysis (h)

TdLN, liver and lung metastasis (Fig. 7d-f; Supplementary information, Fig. S23a) compared to untreated controls. However, celecoxib treatment at 1 week after castration (celecoxib ${ }^{\text {Week }}{ }^{1}$ ) unexpectedly enhanced tumor cell invasion and proliferation (Fig. 7b, c). These results were confirmed by flow cytometric data, which showed that the percentage of $C D 4^{\text {low }} \mathrm{T}$ cells was significantly decreased in the celecoxib ${ }^{\text {week } 8}$ treatment group whereas the celecoxib week 1 treatment failed to inhibit the accumulation of CD4 ${ }^{\text {low }} \mathrm{T}$ cells (Fig. $7 \mathrm{~g}$; Supplementary information, Fig. S23b-e). Importantly, the celecoxib ${ }^{\text {week } 8}$ but not celecoxib $^{\text {week }} 1$ treatment group showed remarkably longer survival times than the untreated controls (Fig. 7h).

To examine the possible source of the adverse effects of the celecoxib week 1 treatment, the level of $\mathrm{PGE}_{2}$ in the serum and EP2 expression in $\mathrm{CD}^{+}{ }^{+}$cells isolated from peripheral blood during the celecoxib treatment were examined by ELISA and RT-PCR, respectively. The results showed that the levels of $P G E_{2}$ were indeed decreased at about 3 weeks after drug treatment, although these levels slightly increased later (Fig. 7i) whereas EP2 expression gradually increased starting from 5 weeks after celecoxib treatment (Fig. 7j). These results suggest that a compensatory elevation of EP2 expression in T cells, which reactivates $P G E_{2}-E P 2$ signaling to promote the generation of CD4 ${ }^{\text {low }} \mathrm{T}$ cells (Fig. 7g), might explain the adverse effects of celecoxib ${ }^{\text {week } 1}$ treatment. Thus, collectively, these results indicate that $C D 4^{\text {low }} \mathrm{T}$ cells could be used as specific indicators of the effectiveness of celecoxib treatment for PCa with ADT.

\section{DISCUSSION}

Over the past several decades, a number of studies have attempted to apply immunotherapy to improve the overall survival in prostate cancer mouse models and patients with $\mathrm{ADT}^{45}$ However, the therapeutic outcomes have not been particularly positive so far. In this study, we observed that a novel population of $\mathrm{CD}^{\text {low }}{ }^{\mathrm{HLA}-\mathrm{G}^{+}} \mathrm{T}$ cells expands in both PCa patients and mouse models at an early stage of CRPC. This expansion is correlated with CRPC occurrence in patients and essential for CRPC onset in mouse models. Functional analysis demonstrated that these cells are IL-4-expressing $\mathrm{T}_{\mathrm{H}} 17$ cells, which promote androgen-independent growth of PCa cells by modulating the properties of TAMs. By blocking the generation of CD4 ${ }^{\text {low }} \mathrm{HLA}-\mathrm{G}^{+}$ $T$ cells, the onset of CRPC is prevented. Thus, our experiments suggest a new therapeutic approach to overcome castrationresistance of prostate cancer.

Having demonstrate the importance of the $\mathrm{CD} 4{ }^{\text {low }} \mathrm{HLA}_{-\mathrm{G}^{+}} \mathrm{T}$ cell population in the onset of CRPC, we have provided significant insight into the mechanisms responsible for the generation of these cells. A previous study showing that $\mathrm{PGE}_{2}$ could induce $\mathrm{DN}$ cells isolated from the thymus to differentiate into $C D 4^{\text {low }} C D 8^{\text {low }}$ cells in vitro ${ }^{37}$ inspired our investigation of a possible role of $\mathrm{PGE}_{2}$ in the production of CD4 ${ }^{\text {low }} \mathrm{HLA}-\mathrm{G}^{+} \mathrm{T}$ cells. Indeed, we obtained several results that directly support this hypothesis. First, we found that expression levels of $\mathrm{PGE}_{2}$ are significantly increased after androgen ablation in both PCa patients and mouse models. Second, our studies also detected the expansion of CD $4{ }^{\text {low }} C D 8^{\text {low }}$ and $\mathrm{CD}^{\text {low }} \mathrm{CD}^{-}$cells in the thymus of PCa mouse models after castration. Third, $\mathrm{PGE}_{2}$ promotes $\mathrm{DN}$ thymocytes to differentiate into $C D 4^{\text {low }}$ cells in a dose-dependent manner, which is significantly inhibited by an EP2 antagonist in an in vitro culture system. Furthermore, administration of celecoxib, a $\mathrm{PGE}_{2}$ synthesis blocker, dramatically prevents the production of $\mathrm{CD} 4^{\text {low }} \mathrm{CD} 8^{\text {low }}$ and $C D 4^{\text {low }} \mathrm{CD}^{-}$thymocytes as well as peripheral $\mathrm{CD} 4^{\text {low }} \mathrm{T}$ cells in PCa mouse models after androgen ablation. Thus, in total, these results show that $\mathrm{PGE}_{2}$-EP2 signaling induces an aberrant differentiation of thymocytes from DN cells to CD4 ${ }^{\text {low }}$ cells, contributing to the generation of $\mathrm{CD} 4{ }^{\text {low }} \mathrm{HLA}-\mathrm{G}^{+} \mathrm{T}$ cells.

It should be noted that although $\mathrm{PGE}_{2}$ has been shown to have multiple effects in modulating the pro-tumor properties of immune cells in the tumor microenvironment, in addition to a direct role on tumor cells, ${ }^{46}$ its effect on thymocyte differentiation has been rarely mentioned. To the best of our knowledge, the current study is the first report to demonstrate that $\mathrm{PGE}_{2}$ can induce abnormal differentiation of thymocytes from DN cells to CD4 ${ }^{\text {low }}$ cells during the development of prostate cancer after ADT, which is responsible for the generation of CD4 ${ }^{\text {low }} \mathrm{HLA}-\mathrm{G}^{+} \mathrm{T}$ cells. Supporting data for this model also come from other previous studies. For instance, (1) higher levels of $\mathrm{PGE}_{2}$ are not only observed in the present study but have also been seen in many other cancer types, including colorectal cancer, breast cancer and gastric cancer. ${ }^{46}$ (2) There is a close correlation between sex steroids and the rejuvenation of the thymus. ${ }^{47}$ (3) Androgen ablation has a positive effect on the activation of thymic regeneration. ${ }^{6,7,47}$ (4) $T_{H} 17$ cells have been seen to expand in the tumor microenvironment via $\mathrm{PGE}_{2}$ and $\mathrm{PGE}_{2}$-induced upregulation of IL-23R in breast cancer. ${ }^{38,48}$ Therefore, it is likely that in response to the aberrant elevation of $\mathrm{PGE}_{2}$, the thymocytes adopt a different program to differentiate into an unusual subtype of $T$ cells.

Our findings indicate that application of celecoxib starting at different time points after ADT may produce distinct therapeutic outcomes. On the one hand, celecoxib treatment starting at eight weeks after castration, when CD4 ${ }^{\text {low }} \mathrm{HLA}-\mathrm{G}^{+} \mathrm{T}$ cells are detected, dramatically inhibits the occurrence of CRPC, and more importantly prolongs survival times in PCa mouse models. On the other hand, administration of celecoxib immediately following ADT leads to the failure of prostate cancer therapy, with enhanced tumor cell infiltration and proliferation as well as failure to abrogate the production of $\mathrm{CD} 4^{\text {low }} \mathrm{HLA}-\mathrm{G}^{+} \mathrm{T}$ cells in mouse models. A similar phenomenon has been reported in a recent clinical trial for prostate cancer: namely, application of celecoxib and ADT simultaneously does not produce better clinical outcomes than ADT alone. ${ }^{44} \mathrm{~A}$ possible explanation for the difference may be that the long-term use of celecoxib activates a compensatory mechanism to enhance $\mathrm{PGE}_{2}$ synthesis and/or upregulate the expression of proteins in downstream signaling of $\mathrm{PGE}_{2}$. Support for this notion comes from the current study in which long-term use of celecoxib in the PCa mouse models led to compensatory elevation of EP2 expression in T cells, which reactivates $P G E_{2}-E P 2$ signaling to promote the generation of CD4 ${ }^{\text {low }} \mathrm{HLA}-\mathrm{G}^{+} \mathrm{T}$ cells. Similar observations are also reported in intestinal tumors, where long-term use of celecoxib has been 
1114

shown to produce significantly higher levels of $\mathrm{PGE}_{2}$ and reactivation of $\mathrm{PGE}_{2}$-associated signaling pathways in tumors and normal tissues. ${ }^{49}$ Taken together, these results highlight the importance of timing in implementing celecoxib treatment and further, demonstrate that $\mathrm{CD} 4{ }^{\text {low }} \mathrm{HLA}-\mathrm{G}^{+} \mathrm{T}$ cells can be used as an indicative marker of therapeutic efficacy in celecoxib treatment on prostate cancer after ADT.

Several mechanisms underlying androgen-independent growth of prostate cancer cells have been demonstrated, including amplification of the androgen receptor $(A R)$ gene, mutations in the $A R$ gene and AR-independent signaling. ${ }^{50,51}$ Although neuroendocrine prostate cancer only represents a small portion of initially diagnosed prostate cancer, accumulating evidence has suggested that neuroendocrine differentiation (NED) can be induced by ADT. Further, NED is associated with cancer recurrence and poor prognosis, suggesting that NED is one of mechanisms associated with CRPC formation. ${ }^{52,53}$ Thus, although the TRAMP model is a neuroendocrine small cell prostate cancer model, it has its value for the study of the development and biological characteristics of CRPC in humans. More importantly, in our study we used both TRAMP and ProbCre/Pten ${ }^{\text {fl/fl }}$ mice to confirm our findings obtained from PCa patients and found that CD4 ${ }^{\text {low }} \mathrm{T}$ cells appeared after castration in both of these mouse models.

In summary, we have demonstrated that a novel population of CD4 ${ }^{\text {low }} \mathrm{HLA}_{-\mathrm{G}^{+}} \mathrm{T}$ cells induced by $\mathrm{PGE}_{2}$ is expanded in $\mathrm{PCa}$ patients and mouse models after ADT, which impairs the host immune surveillance and converts the tumor microenvironment into a pro-tumor state. Elimination of this population by celecoxib may produce clinical benefit for prostate cancer patients after ADT. Thus, the proper combined use of celecoxib and ADT may sustain the anti-tumor immune response, pointing to a new therapeutic avenue for better prostate cancer management (Supplementary information, Fig. S24).

\section{MATERIALS AND METHODS}

Study design

This was a preclinical study of $\mathrm{CD}^{\text {low }}{ }^{\mathrm{HLA}-\mathrm{G}^{+}} \mathrm{T}$ cells as a prognostic factor and therapeutic target for CRPC. We used blood and tumor samples of $\mathrm{PCa}$ patients to determine whether CD4 ${ }^{\text {low }} \mathrm{HLA}-\mathrm{G}^{+} \mathrm{T}$ cells were specifically expanded in PCa patients after ADT and analyzed the correlation between proportions of $\mathrm{CD}^{\text {low }}{ }^{\mathrm{HLA}-\mathrm{G}^{+}} \mathrm{T}$ cells and the prognosis in PCa/ADT patients. To further study the characteristics of these cells, multiple CRPC murine models were constructed. $\mathrm{CD} 4{ }^{\text {low }} \mathrm{HLA}^{-\mathrm{G}^{+}} \mathrm{T}$ cells were first defined as IL-4-expressing $\mathrm{T}_{\mathrm{H}} 17$ cells in both PCa patients and mouse models by qPCR, intracellular flow cytometry and RNA-seq analysis. And subsequent cell depletion studies and adoptive transfer assays were performed to test if these cells were essential for the formation of CRPC. To analyze the function of CD4 ${ }^{\text {low }} \mathrm{HLA}$ $\mathrm{G}^{+} \mathrm{T}$ cells, an in vitro co-culture system comprising CD4 ${ }^{\text {low }} \mathrm{T}$ cells, macrophages and TRAMP-C1 cells was established and the proliferation of TRAMP-C1 cells after androgen ablation, the polarization of macrophages, and the numbers of migrated macrophages were examined. To explore the effects of $\mathrm{PGE}_{2}$ on the production of $\mathrm{CD}^{\text {low }}{ }^{\mathrm{HLA}-\mathrm{G}^{+}} \mathrm{T}$ cells, DN thymocytes and $C D 4^{\text {low }}$ naïve $T$ cells were cultured in the presence of $P G E_{2}$ in vitro and the percentages of $\mathrm{CD} 4^{\text {low }}$ thymocytes and IL- $4^{+} \mathrm{IL}-17 \mathrm{~A}^{+} \mathrm{CD} 4^{+}$ $T$ cells were measured by flow cytometry, respectively. Finally, we administrated celecoxib, a synthesis blocker of $\mathrm{PGE}_{2}$, and combined with ADT in PCa mouse models that were refractory to ADT alone. Mice were randomized to different treatment groups on the basis of histopathologic features to make sure that all castrated mice in the experiments were formed CRPC. The number of samples is stated in each figure legend and all experiments were performed independently at least three to five times. All data were analyzed and outliers were not excluded.

\section{Human samples}

All human samples were collected with informed consent of patients and the procedures were approved by Renji Hospital of Shanghai Jiao Tong University (Renji [2013] N013). PSA level, Gleason score, TMN stage, tumor grade and medication usage were obtained by review of electronic medical records. Prognostic information was acquired by telephone follow-up. Tumor samples for flow cytometry and immunofluorescence staining were collected from patients that were undergoing prostatectomy at the Department of Urology, Renji Hospital. Blood samples for clinical phenotyping were obtained from patients seen at Renji Hospital.

\section{Animals}

All animal studies were reviewed and approved by the institutional Animal Care and Use Committee of Shanghai Jiao Tong University. All mice were maintained in pathogen-free conditions and cared for in compliance with ethical regulations at Renji Hospital. TRAMP, probCre and Pten ${ }^{f / f l}$ mice were introduced from Jackson laboratory. Mice were castrated at 12-weeks of age and sacrificed 12 weeks post-castration unless indicated otherwise. Prostates, TdLNs, livers and lungs were collected for H\&E and immunohistochemistry staining. The diagnosis of tumor metastasis was made independently by two pathologists. Central and peripheral lymphoid organs were collected for flow cytometry. The genetic backgrounds of all mice used in this study were C57BL/6.

\section{Cells}

TRAMP-C1 murine prostate adenocarcinoma cells were purchased from the American Type Culture Collection (ATCC).

Immune cell isolation

Thymuses were mechanically dissociated and strained through a $40 \mu \mathrm{m}$ nylon mesh to produce a single cell suspension. After RBCs were lysed, cells were stained with CD4 and CD8 antibodies, and $\mathrm{CD} 4^{-} \mathrm{CD}^{-} \mathrm{DN}$ or $\mathrm{CD}^{+}{ }^{+} \mathrm{CD} 8^{+} \mathrm{DP}$ cells were sorted by flow cytometry. For thymic stromal cells, thymuses were digested into single cells using collagenase type IV $(0.5 \mathrm{mg} / \mathrm{mL})$, DNase I ( $2 \mathrm{U} /$ $\mathrm{mL}$ ) for $2 \mathrm{~h}$ at $37^{\circ} \mathrm{C}$. The dissociated cells were collected and cultured with RPMI 1640 medium for 2 days. The suspended cells were removed and remaining cells cultured in RPMI 1640 medium for another 5 days. For naive $\mathrm{CD}^{+}{ }^{+} \mathrm{T}$ cells, cells were isolated with a $\mathrm{CD}^{+}{ }^{+} \mathrm{CD}_{22} \mathrm{~L}^{+} \mathrm{T}$-cell isolation kit II (Miltenyi Biotec). For tumorinfiltrating leukocytes (TILs), tumors were digested into single cells with collagenase type IV $(0.5 \mathrm{mg} / \mathrm{mL})$, hyaluronidase $(10 \mathrm{U} / \mathrm{mL})$ and DNase I $(0.01 \mathrm{mg} / \mathrm{mL})$ for $2 \mathrm{~h}$ at $37^{\circ} \mathrm{C}$. The dissociated cells were collected, lysed with RBC lysis buffer, and then incubated with CD4 monoclonal antibody. For peripheral blood $\mathrm{CD}^{+}{ }^{+} \mathrm{T}$ cells, blood samples were subjected to density centrifugation using Ficoll-hypaque solution to isolate mononuclear cells. After RBCs were lysed, cells were incubated with CD4 antibody and then sorted by flow cytometry.

\section{Cell depletion study}

Male castrated TRAMP and ProbCre/Pten ${ }^{f / f l}$ mice were depleted of $\mathrm{CD} 4{ }^{\text {low }} \mathrm{T}$ cells by intraperitoneal injection of a $250 \mu \mathrm{g}$ CD4neutralizing antibody beginning at 8 weeks post-castration and continuing every 3 days for a total of four times. Control mice were injected intraperitoneally with an isotype control antibody, according to the same dosing schedule. The efficiency of CD4 ${ }^{\text {low }} \mathrm{T}$ cell depletion was verified by flow cytometry. Anti-CD4 antibody (BioXCell, in VivoPlus Rat lgG2b anti-mouse CD4, clone LTF-2, BP0003-1) and isotype control antibody (BioXcell, in VivoPlus Rat lgG2b Isotype control, clone LTF-2, BP0090) were used. Mice were sacrificed at 12 weeks post-castration. Prostates, TdLNs, livers and lungs were collected and performed H\&E and 
immunohistochemistry staining. The progression of primary tumor and incidence of TdLN, liver and lung metastasis were analyzed.

\section{Adoptive transfer assay}

CD4 ${ }^{\text {low }}$ and $\mathrm{CD}^{+} \mathrm{T}$ cells were isolated from peripheral blood of 24-week-old CRPC TRAMP mice and sham-operation controls, respectively, as previously described. Next, a total of $1 \times 10^{6}$ $\mathrm{CD} 4^{\text {low }}$ or $\mathrm{CD}^{+}{ }^{+}$T cells were activated with $3 \mu \mathrm{g} / \mathrm{mL}$ anti-CD3 and $3 \mu \mathrm{g} / \mathrm{ml}$ anti-CD28 antibodies for $6 \mathrm{~h}$. Castrated TRAMP mice received an intravenous injection of $1 \times 10^{6} \mathrm{CD} 4^{\text {low }} \mathrm{T}$ cells beginning at 2 weeks after castration and continuing every two weeks for a total of three times. Control groups were injected intravenously with $1 \times 10^{6} \mathrm{CD}^{+} \mathrm{T}$ cells or a same volume of PBS, according to the same dosing schedule. All mice were sacrificed at 8 weeks post-castration, except for those used in cell tracking assays. Prostates, TdLNs, livers and lungs were collected and performed H\&E and immunohistochemistry staining. The progression of primary tumors and incidence of tumor metastases were analyzed.

If cell tracking was required, $\mathrm{CD} 4^{\text {low }}$ and $\mathrm{CD} 4^{+} \mathrm{T}$ cells were labeled using a Qtracker 565 cell labeling kit (ThermoFisher) and then injected intravenously into castrated TRAMP mice. Mice were sacrificed $24 \mathrm{~h}$ after cell injection. The fluorescence of prostate sections was monitored on a Leica DM2500 fluorescence microscope.

$\mathrm{CD} 4^{\text {low }} \mathrm{T}$ cell-macrophage-TRAMP-C1 cell co-cultures

$\mathrm{CD} 4{ }^{\text {low }} \mathrm{T}$ cells were isolated from primary tumors of CRPC TRAMP mice as previously described. Whole bone marrow cells were isolated from C57BL/6 mice. Macrophages were generated by incubating whole bone marrow cells in macrophage colonystimulating factor (M-CSF, $10 \mathrm{ng} / \mathrm{mL}$ ) for 7 days and harvesting the adherent fraction. For co-culture assays, $5 \times 10^{4}$ macrophages and equal number of TRAMP-C1 cells were added into the upper and bottom chambers of a 24-well Transwell apparatus (Corning), respectively. After $6 \mathrm{~h}$ culture, $2.5 \times 10^{5} \mathrm{CD} 4^{\text {low }}$ T cells activated by a leucocyte activation cocktail (BD Biosciences) were added into the bottom chamber of the Transwell apparatus. After $24 \mathrm{~h}$ of coculture, $C D 4^{\text {low }} T$ cells and macrophages were removed and then TRAMP-C1 cells were treated with $20 \mu \mathrm{M}$ Casodex (Sigma) for 3 days. Cell proliferation of TRAMP-C1 cells was measured by CCK8 assay according to the manufacturer's directions (MedChemExpress). To analyze the polarization of macrophages, macrophages in the co-culture system were collected and examined by flow cytometry using anti-CD80 and anti-CD206 antibodies (ebioscience). To examine the migration of macrophages, cells passing through the membrane of the insert after co-culture were stained by haematoxylin and quantified by counting the number of cells in five high-power fields (HPF) per well. For blocking experiments, $10 \mu \mathrm{g} / \mathrm{mL}$ anti-IL-4 and/or anti-IL-17 were used.

In vitro differentiation of $\mathrm{CD} 4^{\text {low }}$ thymocytes

CD4 ${ }^{-} \mathrm{CD} 8^{-} \mathrm{DN}$ cells and thymic stromal cells were isolated from thymus of C57BL/6 mice as described above. For CD4 ${ }^{\text {low }}$ thymocyte differentiation, $1 \times 10^{5} \mathrm{DN}$ cells were added into 24well plate (Corning) containing thymic stromal cells in the presence of $0.5 \mathrm{ng} / \mathrm{mL} \mathrm{IL-7}$ and different concentrations of $\mathrm{PGE}_{2}$ $\left(10^{-5} \mathrm{M}, 5 \times 10^{-5} \mathrm{M}\right.$ and $\left.10^{-4} \mathrm{M}\right)$. On day 5 , the cells were harvested and analyzed by flow cytometry. For the rescue experiment, $10^{-5} \mathrm{M} \mathrm{AH6809}$ (EP2 antagonist) and/or $10^{-5} \mathrm{M}$ GW627368X (EP4 antagonist) (Cayman chemical) were used.

CD4 ${ }^{\text {low }}$ T-cell polarization

Naïve $C D 4^{+} T$ cells were isolated from spleen of CRPC TRAMP mice and sham-operation controls as previously described. A total of $1 \times 10^{6}$ naive $\mathrm{CD}^{+} \mathrm{T}$ cells were activated with $1 \times 10^{7} \mathrm{~T}$-depleted splenocytes as APC with $3 \mu \mathrm{g} / \mathrm{mL}$ anti-CD3 and $3 \mu \mathrm{g} / \mathrm{mL}$ anti-CD28 antibodies. The activated cells were cultured under $\mathrm{T}_{\mathrm{H}} 2$-polarizing conditions ( $10 \mathrm{ng} / \mathrm{mL}$ IL-4 and $10 \mu \mathrm{g} / \mathrm{mL}$ anti-IFN- $\gamma$ ) for 3 days. Then cells were cultured in the presence of $10^{-4} \mathrm{M} \mathrm{PGE}_{2}$ and/or $10 \mathrm{ng} / \mathrm{mL}$ IL-23 for another 5 days. On day 1, 3 and 5, cells were harvested and analyzed by flow cytometry and RT-PCR. For the rescue experiment, $10^{-5} \mathrm{M}$ AH6809 (EP2 antagonist) and/or $10^{-5}$ M GW627368X (EP4 antagonist) (Cayman chemical) were used.

Immunohistochemistry

Tissues were fixed in $4 \%$ paraformaldehyde overnight and embedded in paraffin. Slides were stained with anti-SV40 T antigen (ab16879, Abcam), anti-a-SMA (ab32575, Abcam) or antiKi67 (ab16667, Abcam).

\section{Immunofluorescence}

$5-\mu \mathrm{m}$ sections of primary prostate carcinoma frozen in OCT were fixed in $4 \%$ paraformaldehyde, and blocked with $10 \%$ normal donkey serum before application of primary antibodies as follows: CD4 (ab133616, Abcam) at a dilution of 1:200, HLA-G (ab7758, Abcam) at a dilution of 1:100. All secondary antibodies were raised in donkey. CD4 was detected using anti-rabbit lgG conjugated to AlexaFluor 594 (Invitrogen), while HLA-G was detected by antimouse IgG conjugated to AlexaFluor 488 (Invitrogen). Slides were mounted using prolong ${ }^{\text {TM }}$ Gold antifade reagent with DAPI (Invitrogen) and imaged using a Leica DM2500 fluorescence microscope.

In vivo treatment

Castrated TRAMP mice were assigned into three experimental groups: a control group (fed with normal food), a celecoxib ${ }^{\text {week } 1}$ treatment group, and a celecoxib ${ }^{\text {week }} 8$ treatment group. Celecoxib was milled into mouse chow at a concentration of $100 \mathrm{mg} / \mathrm{kg}$. For the celecoxib ${ }^{\text {week }} 1$ treatment group, mice were treated with celecoxib at 1 week after castration; the celecoxib ${ }^{\text {week }}$ 8 treatment group were treated with celecoxib at 8 weeks after castration. All mice were sacrificed at 12 weeks post-castration, except for those castrated TRAMP mice treated with celecoxib and subject to survival analysis (The endpoint of survival analysis was 48 weeks). $\mathrm{CD}^{+}{ }^{+} \mathrm{T}$ cells were isolated from peripheral blood and the expression of EP2 was measured by RT-PCR. The percentages of $C D 4^{\text {low }} \mathrm{T}$ cells in thymus, peripheral blood and primary tumor were determined by flow cytometry. Tumors, TdLNs, livers and lungs were collected for $\mathrm{H} \& \mathrm{E}$ and immunohistochemistry to analyze the development of tumor.

\section{RNA sequencing}

The RNA quality and integrity were analyzed by Qubit 2.0 (Life Technologies, USA) and Bioanalyzer 2100 (Agilent, Germany). For library preparation, $3 \mu \mathrm{g}$ total RNA was captured by NEBNext Oligo $\mathrm{d}(\mathrm{T})_{25}$ beads (NEB, USA), sheared to give fragments of approximately $250 \mathrm{bp}$, and reverse transcribed using NEBNext RNA first and second Strand Synthesis Module (NEB, USA). The products were end-repaired, A-tailed and ligated to Illumina sequencing adapters and amplified by PCR. The sequencing library were qualified by Qubit 2.0 (Life technologies, USA) and Bioanalyzer 2100 (Agilent, Germany) and then sequenced using an Illumina Hiseq X-Ten with $2 \times 150$ bp paired-end sequencing, controlled by Hiseq Control Software (HCS). Raw sequence reads were initially examined using FastQC for quality control. Raw reads were processed to trim low quality sequences and adapters using Trimmomatic. Clean reads were then mapped to hg19 for human and $\mathrm{mm} 9$ for mouse using STAR, and only uniquely mapped reads were kept. Read counts were calculated by HTSeqcount. Differential expression analysis was performed using DESeq2.

\section{Statistical analysis}

Statistical analysis of the data was performed using the Student's $t$-test and results were presented as mean \pm SEM unless indicated 
otherwise. $P$ values $<0.05$ were considered significant. Significant differences in survival curves were calculated using the log-rank test. Correlation analysis between percentages of peripheral blood CD4 ${ }^{\text {low }} \mathrm{HLA}_{-\mathrm{G}^{+}} \mathrm{T}$ cells and pathological parameters of PCa/ADT patients was conducted by logistic regression. Unsupervised Kmeans clustering of PCa/ADT patients was performed using SPSS 19.0, $K=2$. The statistical test of incidence of tumor metastasis was performed by $\mathrm{X}^{2}$ test using SPSS19.0.

Data and materials availability

The RNA-seq dataset is available at the GEO database, accession number GSE109844. Detailed materials and methods are available in Supplementary information, Data S1.

\section{ACKNOWLEDGEMENTS}

We thank M.H.Y. for his suggestions and editing. The study is supported by funds to Y.Z. from the National Natural Science Foundation of China (NSFC, 81372257 and 81773250), to W.Q.G. from the Chinese Ministry of Science and Technology (2017YFA0102900), NSFC 81630073 and 81872406, Science and Technology Commission of Shanghai Municipality (16JC1405700) and KC Wong foundation, and to W.L. from NSFC 81400458.

\section{AUTHOR CONTRIBUTIONS}

W.Q.G., Y.Z. and C.W. conceived the project, performed experiments, analyzed data, and wrote the manuscript. Q.F.Z. performed experiments and analyzed data. B.Z. and J.H.C. analyzed RNA-seq data. S.B.Z. and Y.J.X. performed immunohistochemical analysis. W.L. and F.W. assisted with flow cytometry. All authors discussed the results and commented on the manuscript.

\section{ADDITIONAL INFORMATION}

Supplementary information accompanies this paper at https://doi.org/10.1038/ s41422-018-0089-4.

Competing interests: The authors declare no competing interests.

\section{REFERENCES}

1. Siegel, R. L., Miller, K. D. \& Jemal, A. Cancer statistics, 2017. CA Cancer J. Clin. 67, 7-30 (2017)

2. Warde, P. et al. Combined androgen deprivation therapy and radiation therapy for locally advanced prostate cancer: A randomised, phase 3 trial. Lancet 378, 2104-2111 (2011).

3. Widmark, A. et al. Endocrine treatment, with or without radiotherapy, in locally advanced prostate cancer (SPCG-7/SFUO-3): an open randomised phase III trial. Lancet 373, 301-308 (2009).

4. Watson, P. A., Arora, V. K. \& Sawyers, C. L. Emerging mechanisms of resistance to androgen receptor inhibitors in prostate cancer. Nat. Rev. Cancer 15, 701-711 (2015).

5. Pu, Y. et al. Androgen receptor antagonists compromise $\mathrm{T}$ cell response against prostate cancer leading to early tumor relapse. Sci. Transl. Med. 8, 333ra47 -333ra47 (2016).

6. Radojević, K. et al. Neonatal castration affects intrathymic kinetics of T-cell differentiation and the spleen T-cell level. J. Endocrinol. 192, 669-682 (2007).

7. Sutherland, J. S. et al. Activation of thymic regeneration in mice and humans following androgen blockade. J. Immunol. 175, 2741-2753 (2005).

8. Drake, C. G. et al. Androgen ablation mitigates tolerance to a prostate/prostate cancer-restricted antigen. Cancer Cell 7, 239-249 (2005).

9. Gannon, P. O. et al. Characterization of the intra-prostatic immune cell infiltration in androgen-deprived prostate cancer patients. J. Immunol. Methods 348, 9-17 (2009).

10. Atala, A. B-cell-derived lymphotoxin promotes castration-resistant prostate cancer. Nature 464, 302 (2010).

11. Hölzel, M., Bovier, A. \& Tüting, T. Plasticity of tumour and immune cells: a source of heterogeneity and a cause for therapy resistance? Nat. Rev. Cancer 13, 365-376 (2013).

12. Kanno, Y., Vahedi, G., Hirahara, K., Singleton, K. \& O'Shea, J. J. Transcriptional and epigenetic control of $\mathrm{T}$ helper cell specification: molecular mechanisms underlying commitment and plasticity. Annu Rev. Immunol. 30, 707-731 (2012).
13. Qian, B. Z. \& Pollard, J. W. Macrophage diversity enhances tumor progression and metastasis. Cell 141, 39-51 (2010).

14. DuPage, M. \& Bluestone, J. A. Harnessing the plasticity of CD4 + T cells to treat immune-mediated disease. Nat. Rev. Immunol. 16, 149-163 (2016).

15. Wang, Y.-H. et al. A novel subset of $\mathrm{CD} 4{ }^{+} \mathrm{T}_{\mathrm{H}} 2$ memory/effector cells that produce inflammatory IL-17 cytokine and promote the exacerbation of chronic allergic asthma. J. Exp. Med 207, 2479-2491 (2010).

16. Dominguez-Villar, M., Baecher-Allan, C. M. \& Hafler, D. A. Identification of T helper type 1-like, Foxp3 + regulatory T cells in human autoimmune disease. Nat. Med 17, 673-675 (2011).

17. Koenen, H. J. P. M. et al. Human CD25 high Foxp3 pos regulatory T cells differentiate into IL-17 - producing cells. Blood 112, 2340-2352 (2008).

18. Bending, D. et al. Highly purified Th17 cells from BDC2. 5NOD mice convert into Th1-like cells in NOD / SCID recipient mice. J. Clin. Invest 119, 565-572 (2009).

19. Harbour, S. N., Maynard, C. L., Zindl, C. L., Schoeb, T. R. \& Weaver, C. T. Th17 cells give rise to Th1 cells that are required for the pathogenesis of colitis. Proc. Natl. Acad. Sci. 112, 7061-7066 (2015).

20. Naji, $A$. et al. CD3 + CD4 low and CD3 + CD8 low are induced by HLA-G: novel human peripheral blood suppressor T-cell subsets involved in transplant acceptance. Blood 110, 3936-3948 (2007).

21. Dianzani, U. et al. Expansion of T cells expressing low CD4 or CD8 levels in B-cell chronic lymphocytic leukemia: correlation with disease status and neoplastic phenotype. Blood 83, 2198-2205 (1994).

22. Pesenti, E. et al. Role of CD4 and CCR5 levels in the susceptibility of primary macrophages to infection by CCR5-dependent HIV type 1 isolates. AIDS Res Hum. Retrovir. 15, 983-987 (1999).

23. Greenberg, N. M. et al. Prostate cancer in a transgenic mouse. Proc. Natl. Acad. Sci. U. S. A. 92, 3439-3443 (1995).

24. Gingrich, J. R. et al. Androgen-independent prostate cancer progression in the TRAMP model. Cancer Res 57, 4687-4691 (1997).

25. Comiskey, M. et al. Evidence that HLA-G is the functional homolog of mouse Qa2, the ped gene product. Hum. Immunol. 64, 999-1004 (2003).

26. Zhang, Q. et al. CCL5-mediated Th2 immune polarization promotes metastasis in luminal breast cancer. Cancer Res 75, 4312-4321 (2015).

27. DeNardo, D. G. et al. CD4 + T cells regulate pulmonary metastasis of mammary carcinomas by enhancing Protumor Properties of Macrophages. Cancer Cell 16, 91-102 (2009).

28. Gomes, A. L. et al. Metabolic inflammation-associated IL-17A causes nonalcoholic steatohepatitis and hepatocellular carcinoma. Cancer Cell 30, 161-175 (2016).

29. Chung, A. S. et al. An interleukin-17-mediated paracrine network promotes tumor resistance to anti-angiogenic therapy. Nat. Med 19, 1114-1123 (2013).

30. Chang, S. H. et al. T helper 17 cells play a critical pathogenic role in lung cancer. Proc. Natl. Acad. Sci. U. S. A. 111, 5664-5669 (2014).

31. Zanganeh, S. et al. Iron oxide nanoparticles inhibit tumour growth by inducing pro-inflammatory macrophage polarization in tumour tissues. Nat. Nanotechnol. 11, 986-994 (2016).

32. Tymoszuk, P. et al. In situ proliferation contributes to accumulation of tumorassociated macrophages in spontaneous mammary tumors. Eur. J. Immunol. 44, 2247-2262 (2014).

33. Foster, B. A., Gingrich, J. R., Kwon, E. D., Madias, C. \& Greenberg, N. M. Characterization of prostatic epithelial cell lines derived from transgenic adenocarcinoma of the mouse prostate (TRAMP) model. Cancer Res 57, 3325-3330 (1997).

34. Savino, W., Mendes-da-Cruz, D. A., Lepletier, A. \& Dardenne, M. Hormonal control of T-cell development in health and disease. Nat. Rev. Endocrinol. 12, 77-89 (2016).

35. Qu, P., Du, H., Wilkes, D. S. \& Yan, C. Critical roles of lysosomal acid lipase in T cell development and function. Am. J. Pathol. 174, 944-956 (2009).

36. Almena, M., Andrada, E., Liebana, R. \& Merida, I. Diacylglycerol metabolism attenuates T-cell receptor signaling and alters thymocyte differentiation. Cell Death Dis. 4, e912 (2013).

37. Monier, J. \& Paradin, R. G. Effects of PGE2 upon differentiation and programmed cell death of suspension cultured CD4-CD8- thymocytes. Int. J. Immunopharmac. 16, 775 (1994).

38. Boniface, K. et al. Prostaglandin E2 regulates Th17 cell differentiation and function through cyclic AMP and EP2/EP4 receptor signaling. J. Exp. Med 206, 535-548 (2009).

39. Basler, J. W. \& Piazza, G. A. Nonsteroidal anti-inflammatory drugs and cyclooxygenase-2 selective inhibitors for prostate cancer chemoprevention. J. Urol. 171, S59-S62 (2004).

40. Drew, D. A., Cao, Y. \& Chan, A. T. Aspirin and colorectal cancer: the promise of precision chemoprevention. Nat. Rev. Cancer 16, 173-186 (2016).

41. Roy, HK et al. Spectral biomarkers for chemoprevention of colonic neoplasia: a placebo-controlled double-blinded trial with aspirin. Gut 66, 285-292 (2017). 
42. Cuzick, J. et al. Prevention and early detection of prostate cancer. Lancet Oncol. 15, e484-e492 (2014).

43. Burn, J. et al. Long-term effect of aspirin on cancer risk in carriers of hereditary colorectal cancer: An analysis from the CAPP2 randomised controlled trial. Lancet 378, 2081-2087 (2011).

44. James, N. D. et al. Celecoxib plus hormone therapy versus hormone therapy alone for hormone-sensitive prostate cancer: first results from the STAMPEDE multiarm, multistage, randomised controlled trial. Lancet Oncol. 13, 549-558 (2012).

45. Karan, D., Holzbeierlein, J. M., Van Veldhuizen, P. \& Thrasher, J. B. Cancer immunotherapy: a paradigm shift for prostate cancer treatment. Nat. Rev. Urol. 9, 376-385 (2012).

46. Nakanishi, M. \& Rosenberg, D. W. Multifaceted roles of PGE2 in inflammation and cancer. Semin Immunopathol. 35, 123-137 (2013).

47. Ventevogel, M. S. \& Sempowski, G. D. Thymic rejuvenation and aging. Curr. Opin. Immunol. 25, 516-522 (2013).
48. Qian, X. et al. Increased Th17 cells in the tumor microenvironment is mediated by IL-23 via tumor-secreted prostaglandin E2. J. Immunol. 190, 5894-5902 (2013).

49. Carothers, A. M., Moran, A. E., Cho, N. L., Redston, M. \& Bertagnolli, M. M. Changes in antitumor response in $\mathrm{C} 57 \mathrm{BL} / 6 \mathrm{~J}-\mathrm{Min} /+$ mice during long-term administration of a selective cyclooxygenase-2 inhibitor. Cancer Res 66, 6432-6438 (2006).

50. Karantanos, T. et al. Understanding the mechanisms of androgen deprivation resistance in prostate cancer at the molecular level. Eur. Urol. 67, 470-479 (2015).

51. Shen, M. \& Abate-Shen, C. Molecular genetics of prostate cancer: new prospects for old challenges. Genes Dev. 24, 1967-2000 (2010).

52. Santoni, M. et al. Neuroendocrine differentiation in prostate cancer: novel morphological insights and future therapeutic perspectives. Biochim. Biophys. Acta Rev. Cancer 1846, 630-637 (2014).

53. Hirano, D., Okada, Y., Minei, S., Takimoto, Y. \& Nemoto, N. Neuroendocrine differentiation in hormone refractory prostate cancer following androgen deprivation therapy. Eur. Urol. 45, 586-592 (2004). 